\title{
Green synthesis of silver nanoparticles with algae and the importance of capping agents in the process
}

\author{
Deeksha Chugh ${ }^{\dagger}$, V. S. Viswamalya ${ }^{\dagger}$ and Bannhi Das ${ }^{*}$ (]
}

\begin{abstract}
Background: Nanoparticle synthesis is a very interesting area of research currently due to the wide applications of nanoparticles. The nanoparticles have a diameter ranging between 1 and $100 \mathrm{~nm}$ and they are used in different fields like electronics, pharmaceuticals, cosmetics, biotechnology, medicines, etc.

Main body of the abstract: Nanoparticles have gained the interest of researchers due to their large surface-tovolume ratio and their capability to interact effectively with other particles. Several different methods can be used for the production of silver nanoparticles (AgNPs) including chemical, physical, and biological. Out of all the methods, the biological method is considered the cleanest and safest as no toxic chemicals are used in the process. The biological method includes the use of bacteria, fungi, algae, and plant extract for the synthesis. Algal synthesis of AgNPs is especially interesting because of the high capacity of the algae to take in metals and reduce metal ions. Algae is a widely distributed organism and its availability is abundant; an added advantage is their growth under laboratory conditions. These organisms can help in large-scale production at a low cost.

Short conclusion: This review article explains the different factors that should be considered for the effective synthesis of AgNPs using algae. Capping agents also affect the stability of nanoparticles. It also sheds light on the importance of capping agents in the synthesis of AgNPs. Alga-mediated synthesis of AgNPs along with the use of different capping agents can help in modulating the stability and size of the nanoparticles, thereby improving its cost-effectiveness and environment-friendly production.
\end{abstract}

Keywords: Algal synthesis, Capping agent, Green synthesis, Silver nanoparticles, Transmission electron microscope

\section{Background}

There are several different microorganisms like bacteria, molds, fungi, etc. that are known to cause infection in humans and other living organisms. To combat these infections, several antibiotic and antimicrobial compounds have been discovered. But, slowly with time, microorganisms started exhibiting resistance against most of the antibiotics thereby creating a problem in treating these microbial diseases [1]. Researchers have been focusing on alternative therapies or methods that can

\footnotetext{
*Correspondence: bannhi.das@gmail.com

${ }^{\dagger}$ Deeksha Chugh and V. S. Viswamalya contributed equally to this work. Department of Biotechnology, Mount Carmel College, Autonomous, Bangalore 560052, India
}

overcome this antibiotic resistance along with costeffectiveness [2]. Nanoparticles (NP) are being considered as a good alternative candidate in many cases.

For over the last 2000 years, silver has been known for its medicinal properties as they possess broad-spectrum antimicrobial activity. There are several different modes by which silver shows inhibitory action against microorganisms. Silver-based products have a lesser tendency to induce antimicrobial resistance and are cost-efficient [2, 3]. Nanotechnology is a relatively new discipline and one of the fast-growing areas of science. It is of great interest to researchers due to its wide application in industries like food, cosmetics, medicines, agriculture, chemical, and pharmaceuticals. Nanotechnology is concerned with

\section{Springer Open}

(c) The Author(s). 2021 Open Access This article is licensed under a Creative Commons Attribution 4.0 International License, which permits use, sharing, adaptation, distribution and reproduction in any medium or format, as long as you give appropriate credit to the original author(s) and the source, provide a link to the Creative Commons licence, and indicate if changes were made. The images or other third party material in this article are included in the article's Creative Commons licence, unless indicated otherwise in a credit line to the material. If material is not included in the article's Creative Commons licence and your intended use is not permitted by statutory regulation or exceeds the permitted use, you will need to obtain permission directly from the copyright holder. To view a copy of this licence, visit http://creativecommons.org/licenses/by/4.0/. 
the synthesis, design, and exploitation of the structure of a particle ranging in size from roughly 1 to $100 \mathrm{~nm}$. It describes how different parameters like origin, structure, and chemical properties can affect the functionality of nanomachinery of cells, and also examine the relation between nanomaterials and nano-biosystems $[4,5]$. The characteristics of nanoparticles depend on several parameters like shape, size, nature of nanoparticles, and surroundings [4-6].

There are several distinct techniques by which silver nanoparticles (AgNP) can be synthesized. They can be produced using physical, chemical, and biological methods. By and large, two approaches are associated with the formation of silver nanoparticles, either from the "top to bottom" approach or a "bottom to top "approach. As the name suggests, in the "bottom to top" approach, smaller atoms of molecules assemble themselves to form nanoparticles. On the other hand, the "top to bottom approach" is the opposite. The synthesis of nanoparticles takes place in this process by breaking down the bulk material into fine size particles using numerous lithographic techniques such as grinding, milling, sputtering, and thermal/laser ablation [5]. The physical method of synthesis involves several different techniques like ball milling, thermal evaporation, ultrathin films, lithographic techniques, plasma arcing, and diffusion flame synthesis [7]. Chemical synthesis is one of the most common methods used to produce silver nanoparticles. Several different chemicals and reagents are used to reduce the silver ions and stabilize the nanoparticles [7-9]. Some of the methods involved in this process are chemical solution deposition, catalytic route, sol-gel process, Langmuir-Blodgett method, wet chemical method, etc. [7]. But one of the biggest drawbacks of this is that the chemicals used for the synthesis are toxic and can be harmful to human health and the environment. So, another approach that gained the attention of several researchers is the use of biological agents or organisms for the synthesis of nanoparticles. This is known as biogenic synthesis and this method has less toxicity, high stability, and better physiochemical characteristics.

Biogenic synthesis of nanoparticles can be carried out by the use of organisms like fungi, algae, bacteria, plants, and their metabolites, which serve as reducing and stabilizing agents $[4-6,8]$. All the different approaches that can be used to synthesize nanoparticles are depicted in Fig. 1.

The antimicrobial activity of AgNPs is due to their combined effects of binding of Ag ions to the cell walls, inactivation of the membrane-associated enzymes, accumulation within the cells, interference with the essential biomolecules of the bacterial cells, denaturation of the cell envelope, and the formation of reactive oxygen species. All of these events are detrimental for the bacterial cells $[2,3,9,10]$. It has been experimentally proven that suspension of AgNPs shows antimicrobial activity against reference and hospital-isolated bacterial strains of Pseudomonas aeruginosa, which were resistant to the multiple antibiotics [11]. Silver nanoparticles exhibit effective antimicrobial properties compared to other nanoparticles because of their extremely large surface area, which offers improved interaction with microorganisms [12]. There are multiple studies that demonstrate that Ag-NPs are effective even at very low concentrations against MRSA (methicillin-resistant Staphylococcus aureus) strains. AgNPs cause a disruption of their cell wall. It can act as an effective substitute for the treatment of medical device-associated infections caused by drugresistant strains of bacteria [3, 13]. Moreover, AgNPs are also used in the electronics and electric field due to their high stability, conductivity, and high performance.

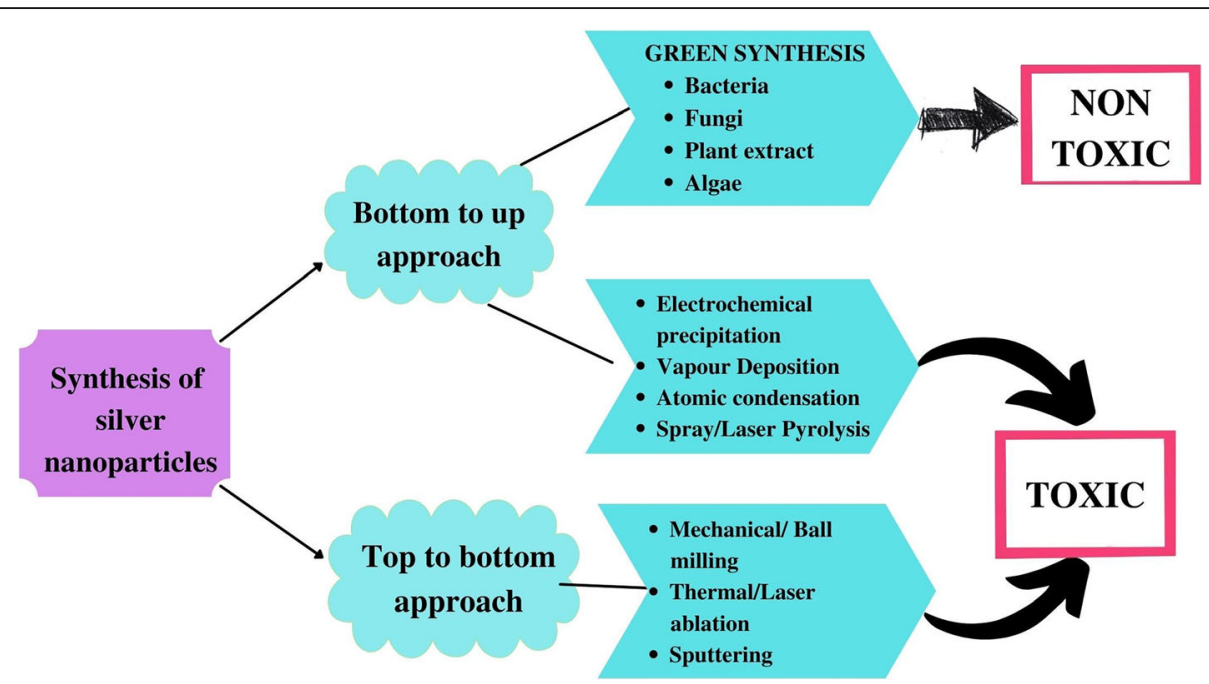

Fig. 1 Different approaches that can be used for the synthesis of silver nanoparticles 
AgNPs are also in demand in the textile industry and the food and beverages industry for food storage and packing purposes [14]. Recently, they have been successfully applied for the detection and treatment of cancer also [5]. The projected market value of nanoparticles for their antimicrobial role has increased from $\$ 0.79$ billion in 2014 to $\$ 2.54$ billion in 2022 [15]. In this article, we have focused on the different methods used to date for the green synthesis of silver nanoparticles with a special emphasis on algae. We have attempted to bring in the factors that can help in modulating the process of synthesis. An in-depth discussion is expected to provide insight into the algal production of AgNP.

\section{Applications of silver nanoparticles}

AgNP has unique physical, chemical, and electrical properties, and because of this, they have several applications in different fields like medicines, optics, water treatment, food industry, etc. (Fig. 2). They can be integrated into composite fibres, cryogenic superconducting materials, and electronic components. Due to its wide range of applications, there is a requirement for advancement in a costeffective method for synthesis. AgNPs are used extensively in the field of medicine due to the spread of infectious diseases and the emergence of multidrug resistance in pathogens which is rendering the existing antibiotics ineffective $[10,16]$. AgNPs are being exploited in the pharmaceutical industry due to their low toxicity in the cells of humans and their stability at various temperatures. Due to these extensive applications of AgNPs, their synthesis has gained a lot of attention from researchers worldwide $[17,18]$.

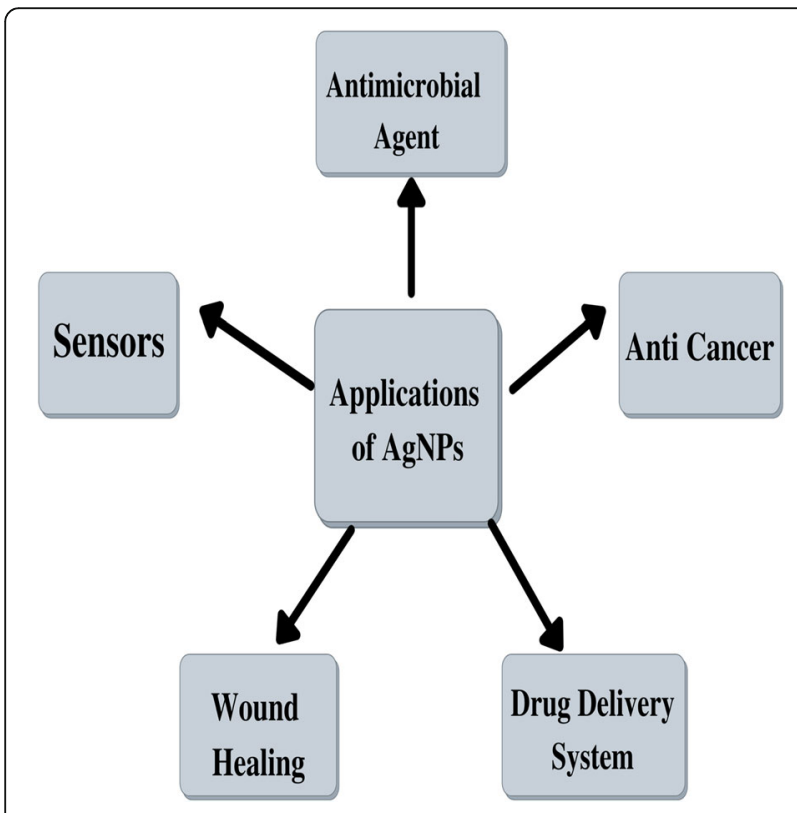

Fig. 2 Applications of silver nanoparticles

\section{Antimicrobial agent}

AgNPs are widely used as antimicrobial agents as they have the potential to overcome antibiotic resistance. They effectively work against gram-positive as well as gram-negative bacteria. It has been reported that AgNP interacts with the bacterial cell wall, penetrates it, and causes serious disturbance in cell functioning which causes cell death $[3,9,19]$. Several different physicochemical parameters affect the antimicrobial properties of AgNPs and they include size, shape, concentration, surface charge, and colloidal state [20]. These physicochemical properties are mostly dependent on the method used for the synthesis of the nanoparticle. The antimicrobial activity exhibited by AgNPs synthesized by different algae is listed in Table 1.

Sondi et al. in an experiment showed that AgNP gets attached to the cell wall of Escherichia coli and form holes on the membrane which ultimately leads to cell death [28]. They also demonstrated that the size of silver nanoparticles influences antimicrobial activity; smaller particles were more potent than the larger-size particles [28]. AgNPs show both bactericidal and bacteriostatic activity against biofilm-forming organisms. Raffi et al. reported that AgNP at a concentration of $60 \mu \mathrm{g} / \mathrm{ml}$ or more is effective in killing E. coli establishing its bactericidal ability [29].

\section{Anti-cancer agents}

Nowadays, AgNPs are widely used as a therapeutic agent, in the diagnosis and treatment of cancer. This is because the toxicity of silver nanoparticles towards cancerous cells is more as compared to the bulk materials. It has been observed that AgNPs acts as an antitumour agent by suppressing tumour cell progression. The probable reason for this can be the inhibitory actions of nanoparticles in several signalling cascades which are required for the development and pathogenesis of cancer. Interestingly, there is no lethal effect of nanoparticles on normal cells [30]. Promising anticancer effects of silver nanoparticles are recently being investigated in different human cancer cell lines, such as endothelial cells, IMR-90 lung fibroblasts, U251 glioblastoma cells, and MDA-MB231 and MCF-7 breast cancer cells [9, 31-33]. Tumour cells require continuous nutrition and oxygen for their growth and this required an intense network of blood vessels that are formed by the process of angiogenesis. AgNP was reported to block the process of angiogenesis thereby suppressing the growth of the tumour. AgNPs synthesized using Ecklonia cava extract were found to be effective against Human cervical cells (HeLa cells) with an IC50 value around $59 \mu \mathrm{g} / \mathrm{ml}[34,35]$.

\section{Drug delivery system}

AgNPs are also being used for targeted drug delivery now a day. Its effectiveness in delivering the anti-cancer drugs 
Table 1 Antimicrobial activity of algae-synthesized silver nanoparticles

\begin{tabular}{|c|c|c|c|c|}
\hline Algae & $\begin{array}{l}\text { Size of NP/ } \\
\text { shape }\end{array}$ & $\begin{array}{l}\text { Volume of NP } \\
\text { used }\end{array}$ & Antimicrobial activity (zone of inhibition) & Reference \\
\hline $\begin{array}{l}\text { Padina } \\
\text { tetrastromatica }\end{array}$ & $14 \mathrm{~nm} / \mathrm{spherical}$ & $30 \mu \mathrm{l}, 60 \mu \mathrm{l}, 90 \mu \mathrm{l}$ & Bacillus sp., Pseudomonas sp., Bacillus subtilis, Klebsiella planticola & [21] \\
\hline $\begin{array}{l}\text { Sargassum } \\
\text { polycystum }\end{array}$ & $\begin{array}{l}5-7 \mathrm{~nm} / \\
\text { spherical }\end{array}$ & $100 \mu \mathrm{l}$ & $\begin{array}{l}\text { Pseudomonas aeruginosa, Klebsiella, Pneumoniae, Escherichia coli, } \\
\text { Staphylococcus aureus }\end{array}$ & [22] \\
\hline Gracilaria corticata & $\begin{array}{l}18-46 \mathrm{~nm} / \\
\text { spherical }\end{array}$ & $30 \mathrm{ml}$ & $\begin{array}{l}\text { C. albicans } \\
\text { C. glabara }\end{array}$ & [23] \\
\hline Gelidiella acerosa & $22 \mathrm{~nm} / \mathrm{spherical}$ & $50 \mu \mathrm{l}$ & Humicola insolens, Fusarium dimerum, Mucor indicus, Trichoderma reesei & [23] \\
\hline $\begin{array}{l}\text { Enteromorpha } \\
\text { flexuosa }\end{array}$ & 2-32 nm/circular & & $\begin{array}{l}\text { B. subtilis, B. pumulis, E. faecalis, S. aureus, S. epidermidis, E. coli, S. cerevisiae, } \\
\text { C. albicans }\end{array}$ & [24] \\
\hline Sargassum wightii & $\begin{array}{l}8-27 \mathrm{~nm} / \\
\text { spherical }\end{array}$ & $30 \mu \mathrm{l}, 60 \mu \mathrm{l}, 90 \mu \mathrm{l}$ & Staphylococcus aureus, Bacillus rhizoids, E. coli, Pseudomonas aeruginosa & [25] \\
\hline Turbinaria conoides & $\begin{array}{l}2-17 \mathrm{~nm} / \\
\text { spherical }\end{array}$ & $50 \mathrm{ml}$ & Salmonella, E. coli, S. liquefaciens, A. hydrophila & [26] \\
\hline Ulva fasciata & $50 \mathrm{~nm} / \mathrm{spherical}$ & $20 \mu \mathrm{l}$ & C. albicans, C. glabrata & {$[27]$} \\
\hline
\end{tabular}

to the tumour tissue has already been observed. The size of the nanoparticles makes it easy for them to penetrate the tissue and ensure effective drug delivery [36]. The use of AgNPs for delivering anti-cancer drugs is of great interest to researchers because of the cytotoxic effect shown by the convention methods of drug delivery [36, 37]. The conventional methods cause the death of the normal or healthy cells along with the tumour cells [37].

\section{Wound healing}

Wound healing is a complicated and time-consuming process as several different cell lineages are involved in this process. There are several extrinsic and intrinsic factors that affect the rate of healing including age, size and depth of the wound, medication, nutritive status, etc. Wound management is very important otherwise there are increased chances of infection at the site of injury which can lead to several complications. A perfect wound dressing maintains a moist environment around the wound, ensures protection against microorganisms, and takes off excess fluids or dead cells [38]. Conventionally, 6 different types of drugs are used for wound management and healing, which include antiseptics, tropical antibiotics, granulation tissue suppressing agents, herbal therapeutics, enzyme treatment, and some other tropical agents (vitamin E, scarlet oil). But there are several limitations or drawbacks related to conventional medication therapy, like narrow antimicrobial spectrum, skin irritation, allergies and cytotoxic effect on body cells, etc. AgNPs can be a perfect alternative for conventional medicines as they have low toxicity to the system, effective against pathogens that are multidrugresistant, and they are not responsible for causing drug resistance due to their multilevel antimicrobial effect [39]. Another advantage of using silver nanoparticles is that it reduces the secretion of cytokines which in turn, decreases the infiltration of mast cells, and therefore, they act as anti-inflammatory agents [40].

\section{Sensors}

Environmental monitoring is the process of accessing the environmental condition to check the concentration of pollutants in the surrounding. Several toxic metals can be present in the environment like mercury, cadmium, lead, copper, nickel, chromium, etc. Due to recent advancements in nanotechnology, it has been found that silver nanoparticles can be efficiently used in optical sensing for the detection of heavy and toxic metals $[9,41]$ (Table 2). Vasileva et al. demonstrated that starch-coated AgNPs of size $15.4 \pm 3.9 \mathrm{~nm}$ in the presence of $\mathrm{HNO}_{3}$ can be effectively used for the quantification of $\mathrm{Hg}^{2+}$ [42]. The principle behind $\mathrm{Hg}^{2+}$ sensing is that the absorbance strength optical response of silver nanoparticles depends on the concentration of $\mathrm{Hg}^{2+}$ in the solution. The most relevant results were obtained when the $\mathrm{Hg}^{2+}$ concentration was in the range of $0.9-12.5 \mu \mathrm{g} \mathrm{L}^{-1}$ and $25-500 \mu \mathrm{g} \mathrm{L}^{-1}$ [42]. Tashkhourian et al. demonstrated the use of chitosan-capped silver nanoparticles (Chit-AgNPs) for the detection of $\mathrm{Fe}^{3+}$ ions [43]. The surface plasmon resonance band of silver nanoparticles disappears at a higher concentration of $\mathrm{Fe}^{3}$. It is a highly sensitive method of detection and can detect concentrations as low as $0.53 \mu \mathrm{M}$ [43].

\section{Solar cell}

One of the recent applications of AgNPs is in the dyesensitized solar cell as they induce surface plasmon resonance which thereby increases the absorption coefficient of dye [53]. Ihara et al. discovered that the efficiency of the dye-sensitized solar cell increased from 1.5 to $2.5 \%$ in the presence of polymer-modified AgNPs. Here, the nanoparticles improved the photoelectric conversion efficiency of the solar cell [54]. 
Table 2 List of silver nanoparticles used for detecting different pollutants

\begin{tabular}{|c|c|c|c|}
\hline Type of Ag nanoparticle & Pollutant detected & Detectable concentration & Reference \\
\hline Riboflavin-stabilized AgNPs & $\mathrm{Hg}^{2+}$ & $5 \mathrm{~nm}$ & [44] \\
\hline 1-Dodecanethiol (C12h25sh)-capped silver nanoprisms & $\mathrm{Hg}(\mathrm{li})$ & $10-500 \mathrm{~nm}$ & [45] \\
\hline Starch-coated AgNps & $\mathrm{Hg}^{2+}$ & $0.9-12.5 \mu \mathrm{g} \mathrm{L} \mathrm{L}^{-1} \& 25-500 \mu \mathrm{g} \mathrm{L}-1$ & [42] \\
\hline 2-Aminopyrimidine-4,6-diol-capped silver nanoparticles (Apd-AgNps) & $\mathrm{Hg}^{2+}$ & $0-65 \mu \mathrm{m}$ & {$[46]$} \\
\hline Citrate (Cit) And L-cysteine (L-Cys)-capped AgNPs & $\mathrm{Hg}^{2+}$ & 1-10 Ppm & [47] \\
\hline Glutathione-stabilized silver nanoparticles & $\mathrm{Ni}^{2+}$ & $>25 \mathrm{~nm}$ & {$[48]$} \\
\hline Casein peptide-capped AgNPs & $\mathrm{Cu}^{2+}$ & $0.08-1.44 \mu \mathrm{m}$ & [49] \\
\hline Chitosan-capped silver nanoparticles (Chit-AgNPs) & $\mathrm{Fe}^{3+}$ & $>0.53 \mu \mathrm{m}$ & [43] \\
\hline Starch-coated silver nanoparticles & $\mathrm{Fe}^{3+}$ & $0.7-7 \mathrm{mg} / \mathrm{l}$ & {$[50]$} \\
\hline L-Tyrosine-stabilized silver nanoparticles & $\mathrm{Mn}(I I)$ & $1-10 \mu \mathrm{m}$ & [51] \\
\hline Tartaric acid-capped silver nanoparticles & $\mathrm{Cr}(\mathrm{III}) \& \mathrm{Cr}(\mathrm{VI})$ & 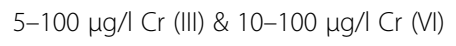 & {$[52]$} \\
\hline
\end{tabular}

\section{Different methods of nanoparticle synthesis}

In light of the wide applications of AgNPs, their synthesis becomes a very crucial factor. Three different approaches can be used for the synthesis of nanoparticles, namely physical, chemical, and biological or green synthesis. Each of these methods can be further classified based on the type of chemical/ physical/ biological component being used in the process.

\section{Physical methods \\ Vapour condensation method}

Vaporization and Condensation are two different steps that are involved in this process and are done at atmospheric pressure using a tube furnace. A heat source is used for the process of vaporization and then these vapours are quickly condensed, resulting in nanoparticle synthesis [55]. However, there are some disadvantages such as high energy usage and time consumption to increase the ambient temperature across the source material and to attain thermal stabilit y[56].

\section{Arc discharge method}

It is another method that can be used for the physical synthesis of nanoparticles. In this method, no surfactants or stabilizers are used and the direct-current arc voltage is applied across two graphite electrodes that are immersed in an inert gas such as $\mathrm{He}, \mathrm{Ar}$, or $\mathrm{Ne}$ [55]. In a study conducted by Tran et al., AgNPs were synthesized in deionized water with no surfactants using the arc discharge method. They used silver wires of 1-mm diameter as electrodes. The results showed that AgNPs synthesized using this method were $10 \mathrm{~nm}$ in diameter [56].

\section{Laser ablation method}

In the laser ablation method, AgNPs can be synthesized in the solution phase with laser ablation on metallic bulk silver salt [55]. It has been shown by Pyatenko et al. that 2-5 $\mathrm{nm}$ of spherical silver nanoparticles can be synthesized in pure water by irradiating the Ag target with the laser beam of wavelength $532 \mathrm{~nm}$. The wavelength of the laser beam and the ablation time are the most important factors that determine the size of synthesized nanoparticles [57].

\section{Chemical Method \\ Chemical reduction method}

This is the most commonly used chemical method that involves the use of a reducing agent and a stabilizing agent/capping. Some of the common reducing agents used for AgNP synthesis are sodium citrate, ascorbate, sodium borohydride $\left(\mathrm{NaBH}_{4}\right)$, elemental hydrogen, polyol process, N, N-dimethylformamide (DMF), and poly (ethylene glycol) block copolymers. The reducing agent reduces $\mathrm{Ag}^{+}$ions to $\mathrm{Ag}$ metal after which they agglomerate into clusters. Cluster formation can be prevented using stabilizing agents/capping agents $[9,58$, 59]. Some of the most commonly used capping agents for the chemical reduction method are citrate, polyvinylpyrrolidone (PVP), cetyltrimethylammonium bromide (CTAB), polyvinyl alcohol (PVA), trisodium citrate, and polyethylene glycol (PEG) $[58,59]$.

\section{Microemulsion method}

This approach includes the use of a mixture of water, surfactant, and oil. Sometimes a co-surfactant is also used along with the other components in this process. The commonly used surfactants are anionic surfactants like bis(2-ethylhexyl) sulfosuccinate, sodium dodecylbenzene sulfonate, and lauryl sodium sulphate and cationic surfactants like CTAB, PVP, and non-ionic surfactants like Triton X-100, etc. The surfactant molecules are surrounded by water droplets, which are like a silver nanoparticle synthesis micro reactor [60].

\section{Polyol process}

This process includes the reduction of silver nitrate $\left(\mathrm{AgNO}_{3}\right)$ at $160{ }^{\circ} \mathrm{C}$ with ethylene glycol. PVP acts as a 
capping agent. The reduction of $\mathrm{AgNO}_{3}$ with ethylene glycol and PVP produces monodisperse Ag nanocubes [61].

\section{Tollens' method}

Tollens' reagent and reducing sugars can also be used for the synthesis of AgNPs. Synthesis with these reagents can be carried out at room temperature and the reducing sugars act both as a reducing agent for the $\mathrm{Ag}^{+}$ions and a stabilizing agent over the AgNP surface producing stable anti-bacterial Ag-NPs [62].

\section{Green synthesis}

Green synthesis is a comparatively more eco-friendly approach for the synthesis of metal nanoparticles than the physical and chemical methods. It involves the use of biological agents such as bacteria, fungi, algae, and plant exacts for the synthesi $\mathrm{s}[7,8,13,63]$.. There are several studies that showed the use of natural polymers like chitosan, soluble starch, polypeptide, heparin, and hyaluronan as capping and reducing agents during the green synthesis of nanoparticles [64]. The process of green synthesis varies based on the type of organism used or the form in which the organisms are used. Some of the synthesis procedure involves live microbial culture, whereas some involve the use of cell extracts or purified biomolecules from them.

\section{Microwave-assisted synthesis}

This method of synthesis involves the use of microwave heating rather than conventional heating during the process of synthesis. The use of a microwave fastens the reaction and ensures uniform heating. This method aids in the synthesis of silver nanoparticles without agglomeration and reduced energy consumption [58]. X. Zhao et al. synthesized AgNPs using microwave irradiation [64]. Alginate was used as a capping and stabilizing agent for the production. This method does not involve any chemical agent as alginate is a naturally occurring carbohydrate that is isolated from sea algae [64].

\section{Biological method}

Biological methods involve the use of plant extracts and microorganisms. The green synthesis by plants involves only the aqueous solution of the $\mathrm{Ag}^{+}$ions and the plant extracts because plants have the properties of detoxification, reduction, and accumulation of metals. Plant extracts contain compounds like polysaccharides, flavonoids, alkaloids, enzymes, polymers, and proteins as reducing agents and even some of them act as capping agents [12, 13, 65]. Different plant extracts are used to synthesize AgNPs from their leaves, roots, stems, and fruits. Plant extracts of Azadirachta indica, Abutilon indicum, Coffea arabica, Jatropha curcas, Ocimum sanctum, Emblica officinalis, Aloe vera, and many more are already being used for AgNP synthesis. The size of the AgNPs synthesized using plant extracts depends on the concentration of the plant extract or the $\mathrm{AgNO}_{3}$ which is the source [14]. Microorganisms like bacteria, fungi, algae, and yeast are employed in the green synthesis of AgNPs.

It has been observed that nanoparticles synthesized by biological methods are capped with biomolecules like alkaloids, phenolic compounds, terpenoids, enzymes, coenzymes, proteins, polysaccharides, lipids, etc. [63]. These biomolecules are present in plants, algae, fungi, bacteria, and yeast. Flavonoids, terpenoids, alkaloids are present in plants. Algal biomolecules are mostly proteins, polyunsaturated fatty acids, vitamins, tocopherols, polyphenols, carotenoids, etc. [63]. However, bacterial and fungal biomolecules that assist in nanoparticle synthesis are mostly Proteins and enzymes [66-69]. Capping agents have multiple roles: prevent agglomeration, reduce toxicity, and increase stability [63].

The green synthesis using microbes is gaining special attention due to the easy handling of microbes, sustainability, and its economic benefit over the other methods [8].

\section{Problems associated with the physical and chemical methods of synthesis}

The different physical and chemical methods mentioned above are extremely expensive and not environmentfriendly. The chemical methods use toxic and hazardous chemicals that pose an environmental and biological risk. The physical methods involve high energy requirements [70]. The physical and photochemical methods require very high temperature, vacuum conditions, and costly equipment, to prepare nanoparticles [71]. Physical and chemical methods are also associated with low production rate, structural particle deformation, and particle growth inhibition during the synthesis of nanoparticles.

The synthesized nanoparticles have a wide array of applications, hence their economic and environmentally safe production is very important [3]. Hence, there is currently an increasing need to improve the sustainable preparation of nanoparticles that minimize the use of hazardous organic chemical compounds [70]. The focus has thus moved from physical and chemical processes to 'green' chemistry and bioprocesses for this synthesis [72].

\section{Biogenic synthesis of silver nanoparticles using algae}

Algae are a group of autotropic organisms with economic and ecological importance. They are single or multicellular organisms that live in different habitats, such as freshwater, marine water, or damp rock surfaces. The two different categories of algae are microalgae 
(microscopic) and macroalgae (macroscopic). They play a vital role in applications such as medicines, pharmacy, forestry, aquaculture, and cosmetics. They are an important source of several commercial products including natural dyes and biofuel [73].

The branch of nanoscience that deals with the synthesis of nanoparticles using algae is termed "Phyconanotechnology". It is a comparatively new branch of nanoscience. Algae are used for the synthesis of nanoparticles as they have a high potential to accumulate metal, are easy to handle and cultivate, can grow at low temperatures, and are less toxic to the environment [74]. Chlorophyceae, Phaeophyceae, Cyanophyceae, and Rhodophyceae are the most common types of algae that are used for the synthesis of silver nanoparticles [73]. Table 3 exhibits AgNPs synthesized by different species of algae, along with the size and shape of the NPs synthesized.

There are several different parameters that can alter the physical and chemical properties of NPs like shape, size, and stability. These parameters include temperature, $\mathrm{pH}$, initial concentration and type of the metals, duration of the exposure, type and concentration of the reducing agents in the aqueous phase, etc. [90].

\section{Algae as one of the most appropriate agents for biological AgNP synthesis}

These days, the use of algae for the biosynthesis of nanoparticles is prevalent. The use of algae is mainly due to their high capacity to take in metals and reduce metal ions, relatively low production costs, and most importantly their ability to produce nanoparticles at a large scale [91, 92]. Another interesting feature is their ability to tolerate harsh atmospheric conditions more effectively than other microorganisms [93]. Both live and dead dry biomass of algae can be used for nanoparticle biosynthesis, and hence, they are known as "Bionanofactories "[94]. Another added advantage of using algae is the time required for the synthesis of silver nanoparticles. Alga-mediated synthesis requires less time compared to other microbes. The time required by $E$. coli to synthesize AgNPs was around $60 \mathrm{~h}$ [95] whereas $\mathrm{Cau}$ lerpa racemose produced nanoparticles in just $3 \mathrm{~h}$ [83]. Silver nanoparticles synthesized by algae contain hydrophilic surface groups such as sulphate, carboxyl, and hydroxyl which gives them unique applicability. They can be used in medical treatment as algae themselves do not fabricate any toxic or harmful substance [15].

\section{Different methods of algal nanoparticle synthesis}

Usually, an algal species synthesized NP by accumulating and subsequently reducing the cations. They can be synthesized from algal biomass using either the extracellular or intracellular mechanism (Fig. 3). There are many different approaches that can be employed for the biosynthesis of algal nanoparticles (Fig. 3).

The bio-reduction of a metal ion to its nanoparticle occurs on the surface of the algal cell in the extracellular pathway whereas in the intra-cellular mechanism the bio-reduction through enzymatic activity occurs inside the cell wall and cell membrane [74].

However, most studies related to the synthesis of silver nanoparticles with the algal biomass involve:

Table 3 Properties of silver nanoparticles synthesized using various classes of potential algae

\begin{tabular}{|c|c|c|c|c|c|c|}
\hline Algae & Species & Synthesis & Size of $\mathrm{Np}(\mathrm{Nm})$ & Shape & Temp. & Reference \\
\hline \multirow[t]{4}{*}{ Cyanobacteria } & Microcoleus & Extracellular & $44-79$ & Spherical & RT & [75] \\
\hline & Phormidium willei & Extracellular & $100-200$ & Spherical & 25 & {$[76]$} \\
\hline & Plectonema boryanum & $\begin{array}{l}\text { Intracellular \& } \\
\text { Extracellular }\end{array}$ & $1-15,1-40,5-200$ & $\begin{array}{l}\text { Spherical \& } \\
\text { octahedral }\end{array}$ & $\begin{array}{l}25,60,100 \\
{ }^{\circ} \mathrm{C}\end{array}$ & [77] \\
\hline & Spirulina platensis & Extracellular & $\sim 12$ & Spherical & 25 & {$[78,79]$} \\
\hline \multirow[t]{3}{*}{ Microalgae } & $\begin{array}{l}\text { Chlamydomonas } \\
\text { reinhardtii }\end{array}$ & $\begin{array}{l}\text { Intracellular \& } \\
\text { extracellular }\end{array}$ & $\begin{array}{l}\text { 5-15(in vitro), 5-35 } \\
\text { (in vivo) }\end{array}$ & Round/rectangular & RT & {$[17]$} \\
\hline & Chlorella vulgaris & Intracellular & $\sim 10$ & Spherical & 28 & {$[80,81]$} \\
\hline & Nannochloropsis oculate & Intracellular & $\sim 19$ & Spherical & 28 & {$[82]$} \\
\hline \multirow[t]{8}{*}{ Macroalgae } & Caulerpa racemose & Extracellular & $5-25$ & Spherical/triangular & RT & [83] \\
\hline & Codium capitatum & - & $\sim 30$ & & RT & {$[84]$} \\
\hline & Ulva fasciata & Extracellular & $28-41$ & Spherical & RT & {$[85]$} \\
\hline & Padina gymnospor & - & $25-40$ & Spherical & 30 & {$[86]$} \\
\hline & Padina pavonica & Extracellular & $45-64$ & Spherical & - & {$[87]$} \\
\hline & Gelidiella acerosa & - & 22 & Spherical & RT & [23] \\
\hline & Gracilaria dura & - & 6 & Spherical & $25,60 \& 100$ & {$[88]$} \\
\hline & Hypnea musciformis & - & $40-65$ & Spherical & RT & [89] \\
\hline
\end{tabular}




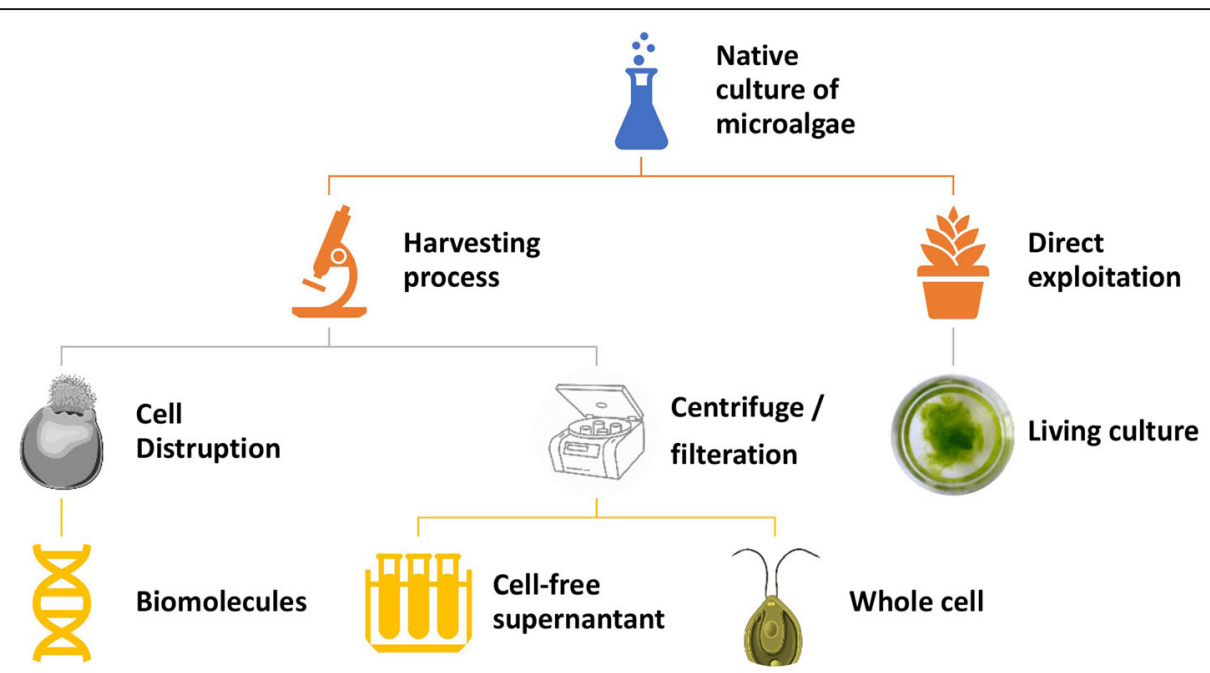

Fig. 3 Different methodologies for the biosynthesis of silver nanoparticles using algae

1. Preparation of algal extract by heating or boiling it in water or organic solvent for a particular time and at a specific temperature.

2. Molar solution preparation of ionic metallic compounds.

3. Incubation of algal solution and molar solutions of ionic metallic compounds for a particular period with either continuous stirring or without stirring in a regulated environment [90].

\section{Synthesis of nanoparticles using living culture}

The use of living algal culture for the production of nanoparticles is one of the simplest methods. In this method, the live culture of algae is used without any additional processing steps. Evidence for the synthesis of $\mathrm{Ag}, \mathrm{Au}$ nanoparticles using living cyanobacterial strains of Anabaena flos-aquae, Calothrix pulvinata, and Leptolyngbya foveolarum are already present. Synthesis can take place across two district pathways. The first one is the intracellular pathway in which the synthesis of nanoparticles occurs within the cell and the other pathway is the extracellular pathway in which the algae secret some bioactive compounds in the surrounding which facilitates the synthesis of nanoparticles. In algae, the extracellular pathway is more prominent than the intracellular pathway. There are numerous reports available in which researchers performed various experiments to synthesize silver nanoparticles using living culture [15]. In a study conducted by Mohseniazar et al., three different genera of microalga living cultures (Nannochloropsis oculata (Ochrophyta), Dunaliella salina, and $C$. vulgaris (Chlorophyta) were exposed to three different concentrations ( $1 \mathrm{mM}, 2 \mathrm{mM}, 5 \mathrm{mM})$ of aqueous $\mathrm{AgNO}_{3}$ solution. They observed that out of three algae, two species, $N$. oculata and $C$. vulgaris, were able to synthesize nanoparticles but only at $1 \mathrm{mM} \mathrm{AgNO}_{3}$ concentration [96].. The study indicates the synthesis of the nanoparticle depends highly on the algal species and the concentration of the $\mathrm{AgNO}_{3}$ solution used in the process. To ensure proper synthesis, optimization of culture conditions is mandatory.

In another experiment performed by Kadukova et al., researchers tried to evaluate the influence of two distinct parameters on the synthesis of silver nanoparticles by Parachlorella kessleri-initial silver concentration and culture age [97]. In this, AgNPs were produced by inoculating the algae in an aqueous solution of $0.5 \mathrm{mM}$ $\mathrm{AgNO}_{3}$. Algal culture grown for 1, 2, 3, and 4 weeks on an agar plate was used to study the effect of culture age. The solution with an Ag+ ion concentration of 0.5, 1, and $2 \mathrm{mM}$ was used for the study of the effect of initial silver concentration. UV-Vis spectroscopy was then used to confirm that the nanoparticles were present. They found that the age of culture has no effect on NP production but the change in initial silver concentration affects the synthesis of AgNP [97].

\section{Synthesis of silver nanoparticles using extracted biomolecules}

Biomolecules are the organic molecules that are present inside the cells. They are mainly composed of carbon, nitrogen, oxygen, hydrogen, phosphorous, and sulphur. Different types of biomolecules include amino acids and proteins, carbohydrates, lipids, nucleic acid, and some small organic molecules [63]. There are several biomolecules reported to be associated with the algal synthesis of AgNP. Table 4 enlists different types of biomolecules, their source algae, and the physical property of AgNPs synthesized by them. 
Table 4 List of biomolecules that are responsible for synthesizing silver nanoparticles

\begin{tabular}{|c|c|c|c|}
\hline Algae & Biomolecule involved in AgNp synthesis & Size/shape & Reference \\
\hline C. reinhardtii & Histone $(\mathrm{H} 4)$ & $\sim 20 \mathrm{~nm}$ & [17] \\
\hline Chlorella vulgaris & Polysaccharide (glucose, fructose, maltose, lactose, rhamnose, arabinose) & $5.76 \mathrm{~nm}$ (average)/spherical & [98] \\
\hline Amphora sp. & Fucoxanthin & $20-25 \mathrm{~nm} / \mathrm{spherical}$ & [99] \\
\hline Navicula (Diatom) & Fucoxanthin & $70-80 \mathrm{~nm}$ & [100] \\
\hline Limnothrix sp. & C-Phycocyanin & $25.65 \pm 2 \mathrm{~nm} /$ spherical \& elongated & [101] \\
\hline Spirulina sp. & C-Phycocyanin & $13.85 \pm 2 \mathrm{~nm} /$ spherical & [101] \\
\hline Laurencia obtusa & Polysaccharides & 4-10nm/spherical & [102] \\
\hline
\end{tabular}

For the extraction of the biomolecules, the cells need to be lysed. There are several methods for algal cell disruption including thermolysis, bead milling, ultrasonication, and laser treatment, grinding, etc. [103]. Once extracted from the cells, it is possible to use these biomolecules for synthesizing silver nanoparticles (Fig. 4).

Xie et al. reported the synthesis of silver nanoparticles with proteins extracted from algae (Chlorella vulgaris) [104]. For this, they used a 10-day-old culture of C. vulgaris and lyophilized it. After lyophilization, filtration was done through Whatman Autovials $(0.45 \mu \mathrm{m})$ and proteins were separated by dialysis. The proteins that were of high molecular weight were collected and called algal proteins $(\mathrm{aP})$. After that, proteins extracted were modified in four different ways to study their effect on the synthesis of nanoparticles using algae. These modifications were as follows: denaturation of aP, tyrosine
(Tyr) residues in aP were chemically modified with the help of N-acetylimidazole (NAI), NAI-modified aP protein was deacetylated of by an inorganic compound hydroxylamine, amination of the carboxyl groups of aP to study their effect on biosynthesis or properties of nanoparticles. The algal extract (i.e proteins) was incubated with $1 \mathrm{mM}$ silver nitrate. Because of surface plasmon resonance (SPR) of Ag nanocrystals in the visible region, the colour of the solution changed from light yellow to pinkish red. A transmission electron microscope (TEM) was performed to determine the shape of AgNPs. During TEM analysis, Ag nanocrystals of three different shapes, i.e. circular, triangular, and rod-like, were observed. This confirmed that proteins extracted were active biomolecules involved in the synthesis of Ag NP. SDS-PAGE (Sodium dodecyl sulphate-polyacrylamide gel electrophoresis) analysis showed that the molecular weight of

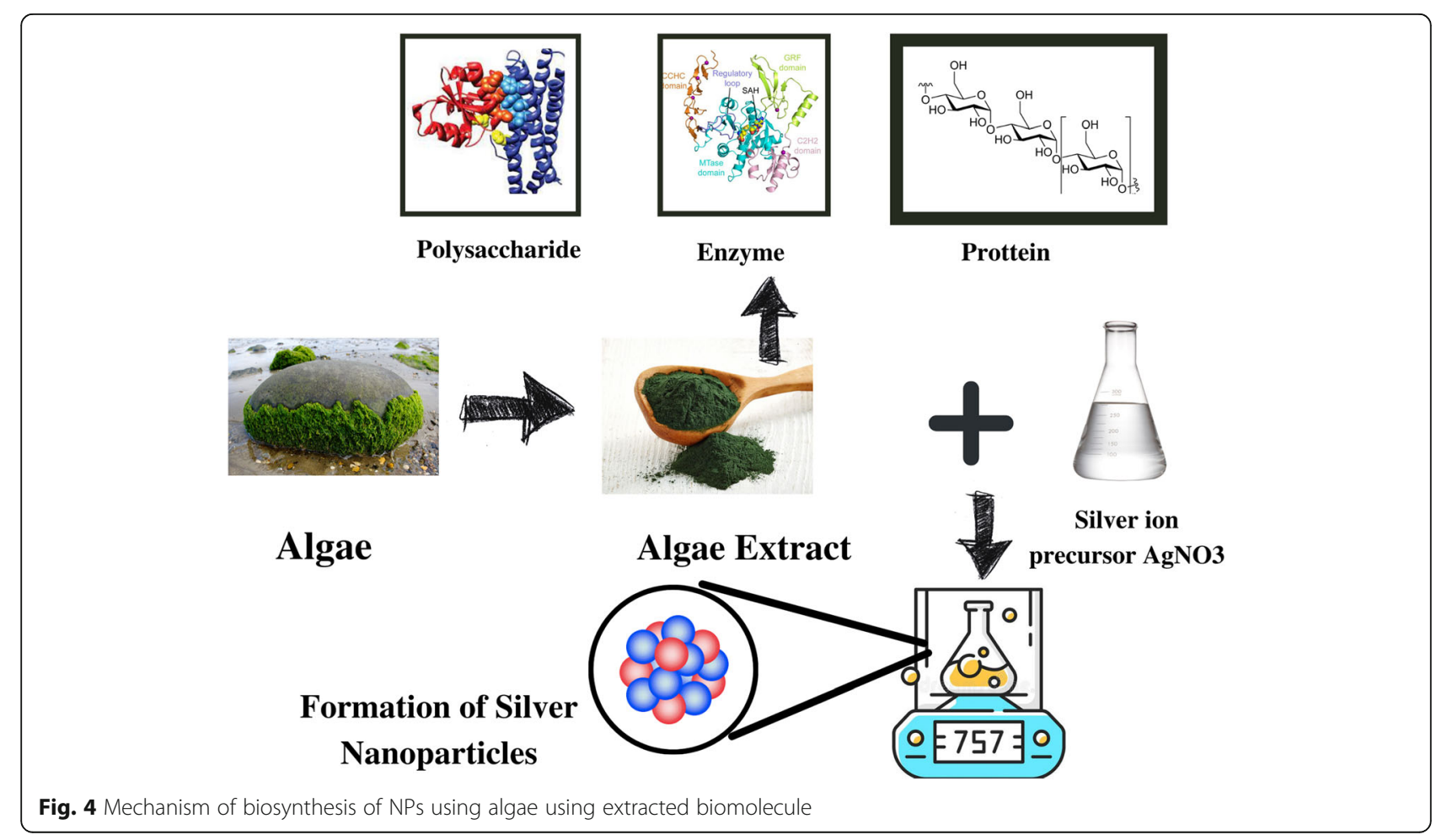


proteins was in a range of $10-50 \mathrm{kDa}$. Through several different experiments, they also found that the hydroxyl group of tyrosine residue is responsible for $\mathrm{Ag}$ ion reduction. In addition, they found that the silver ion reduction kinetics often relies on moieties such as histidine and cysteine residues present in the proteins. Due to carboxyl groups in Asp and/or Glu residues, anisotropic growth of $\mathrm{Ag}$ nanocrystals to nanoplates happens. They also observed that the kinetics of $\mathrm{Ag}$ nanoplate formation was also dependent on the ratio of carboxyl groups to Tyr per peptide molecule [104].

In another experiment by Barwal et al. cellular proteins present in C. reinhardtii viz. histone (H4), carbonic anhydrase $(\mathrm{CA})$, ferredoxin and ferredoxin $\mathrm{NADP}^{+}$reductase (FNR), superoxide dismutase (SOD), sedoheptulose-1, 7bisphosphatase (SBPase), ATP synthase, RuBP carboxylase, and oxygen-evolving enhancer protein (OEE) were associated with biosynthesized of AgNPs. They also found that protein-depleted fractions resulted in the alteration in size and rate of biosynthesis of AgNPs. These results confirmed the involvement of these proteins in C. reinhardtiimediated biosynthesis of AgNPs [105].

Not only proteins even polysaccharides are reported to be involved in AgNP synthesis by algae. According to a report by El-Naggar et al., soluble polysaccharide extracted from Chlorella vulgaris can lead to biosynthesis of AgNPs. Soluble polysaccharide comprises monomeric units of glucose, rhamnose, maltose, lactose, fructose, and arabinose. They reported that the synthesis of NPs occurs after incubating the soluble polysaccharide with $100 \mathrm{mM} \mathrm{AgNO}_{3}$ for $24 \mathrm{~h}$ in dark conditions. TEM analysis of AgNPs found that most of them were spherical with an average size of $5.76 \mathrm{~nm}$ [98].

Other than proteins and polysaccharides, the photosynthetic pigments are also responsible for reducing silver ions to silver nanoparticles. One such research was done by Jena et al., in which they used an aqueous extract of diatom Amphora sp. for pigment-mediated biogenic synthesis of silver nanoparticles. They noticed that there was a higher production of stable silver nanoparticles when the reaction mixture was exposed to light. It was discovered that the light-sensitive photosynthetic pigment fucoxanthin was primarily responsible for the reduction of $\mathrm{Ag}^{+}$to $\mathrm{Ag}^{0}$. Spectroscopic studies have confirmed the development of silver nanoparticles as significant surface plasmon resonance was observed at 415 $\mathrm{nm}$. The size of synthesized nanoparticles was around 20-25 nm and most of them were spherical [99].

\section{Synthesis of silver nanoparticles using cell-free supernatant}

Unlike the previously mentioned methods like the use of live cells or biomolecules extracted from the algae, this method involves the use of cell-free extract. Cell-free extract can be obtained by growing the algae in a liquid culture media and then separating the biomass from the media by centrifugation or filtration. The supernatant obtained by this process can be used for the production of nanoparticles [15, 92] (Fig. 5).

In a research conducted by Sharma et al., biosynthesis of algal silver nanoparticles was carried out using a cellfree extract of Spirulina platensis [106]. For the preparation of the microalga extract, $5 \mathrm{~g}$ of $S$. platensis was suspended in $100 \mathrm{ml}$ of distilled water for $15 \mathrm{~min}$ at $100^{\circ}$ $\mathrm{C}$, and then, after cooling, they centrifuged it at 10,000 rpm for $15 \mathrm{~min}$ and collected the supernatant. Then, for the synthesis of AgNP, $2 \mathrm{ml}$ of the supernatant was added in $100 \mathrm{~mL}$ of $1 \mathrm{mM} \mathrm{AgNO}_{3}$ solution and the flask was kept at $60{ }^{\circ} \mathrm{C}$ for $10 \mathrm{~min}$. After $10 \mathrm{~min}$, the colour of the solution changed from yellow to dark brown which indicates the reduction of $\mathrm{Ag}$ ions to $\mathrm{Ag}$ nanoparticles. Analysis of nanoparticles by TEM revealed that most of the synthesized nanoparticles were spherical and their size ranges between 30 and 50nm [106].

\section{Synthesis of silver nanoparticles using the whole cell}

This process involves the removal of growth media from the algal culture by centrifugation, filtration, or simple washing of the cells. Followed by separation, the algal biomass is used for the synthesis, but before adding to the precursor salt solution, the cells are resuspended into distilled water [15]. The use of the whole cell for the synthesis of AgNP with the help of C. vulgaris was demonstrated by Soleimani and Habibi-Pirkoohi [80]. In this, the cells of C. vulgaris were centrifuged at 5000 rpm for $15 \mathrm{~min}$ at $4{ }^{\circ} \mathrm{C}$. The cells obtained by discarding the supernatant were washed with distilled water and mixed with $200 \mathrm{mM} \mathrm{AgNO}$ in order to get a final concentration of $100 \mathrm{mM}$. After $48 \mathrm{~h}$, the green colour of $C$. vulgaris turned to brown which indicated the presence of silver nanoparticles. A surface plasmon resonance peak was observed in UV-vis spectroscopy at approximately $450 \mathrm{~nm}$ which verified the formation of silver nanoparticles. The synthesized nanoparticles were spherical in shape and were about $10 \mathrm{~nm}$ in size [80]. The whole-cell extract of Plectonema boryanum, Euglena gracilis, and Euglena intermedia (Euglenozoa) have already been reported for the synthesis of silver nanoparticles. However, the major disadvantage of this method is that the cell loses their metabolic activity within hours as they are isolated from their growth media and suspended in distilled water [107].

\section{Factors affecting silver nanoparticle synthesis by algae}

Algal culture in different forms can be used very efficiently for nanoparticle synthesis, but for each of the synthesis process apart from the algae, certain other 

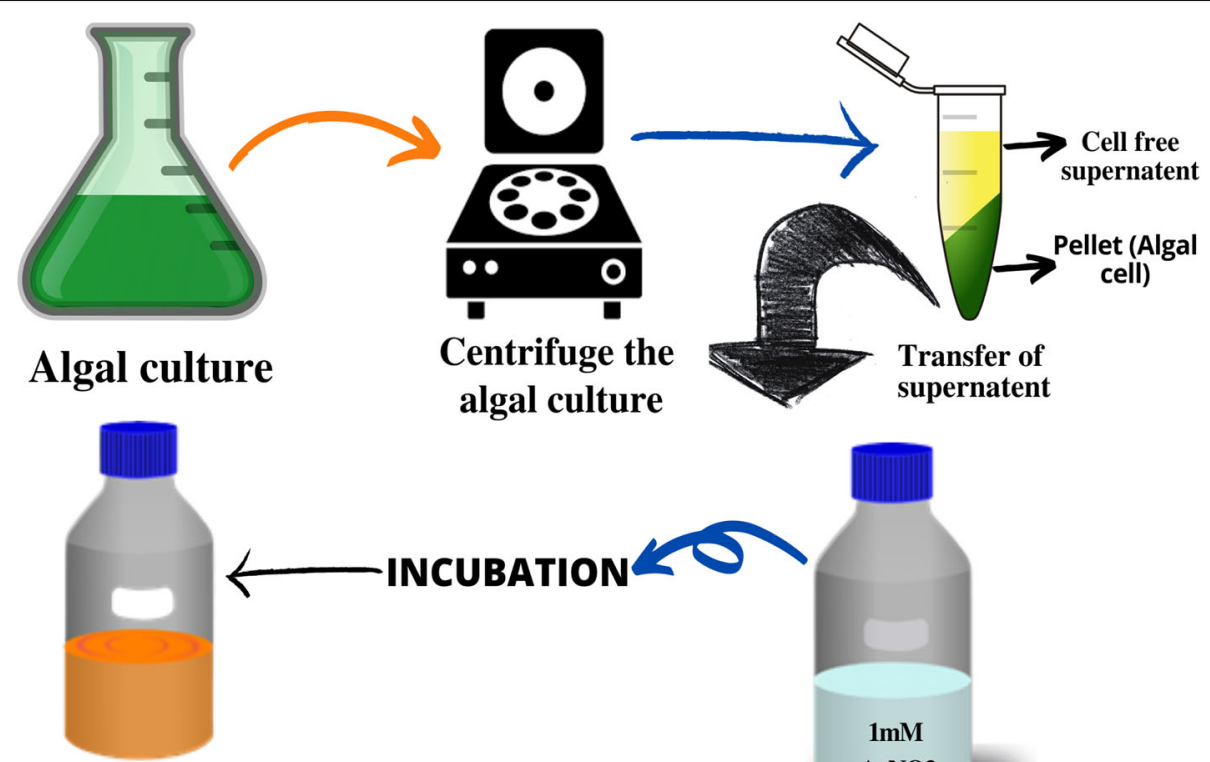

Silver Nanoparticle

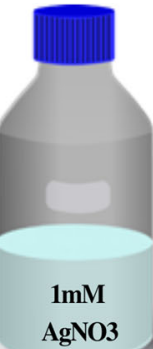
formation

Fig. 5 Mechanism for the synthesis of silver nanoparticles by the cell-free culture of algae

conditions have to be maintained properly. There are several different conditions like, physical, chemical, and environmental factors that affect the biosynthesis of silver nanoparticles with the help of algae. Some of the important factors are extract or biomass concentration, $\mathrm{pH}$, incubation time, illumination, precursor concentration, and temperature (Fig. 6).

\section{Effect of extract concentration}

The concentration of the algal extract is one of the most important factors that influence the biosynthesis of silver nanoparticles. It has been observed that biomass/extract concentration is directly related to the yield of nanoparticles. In addition, the size and structure of nanoparticles are also significantly influenced by the concentration of

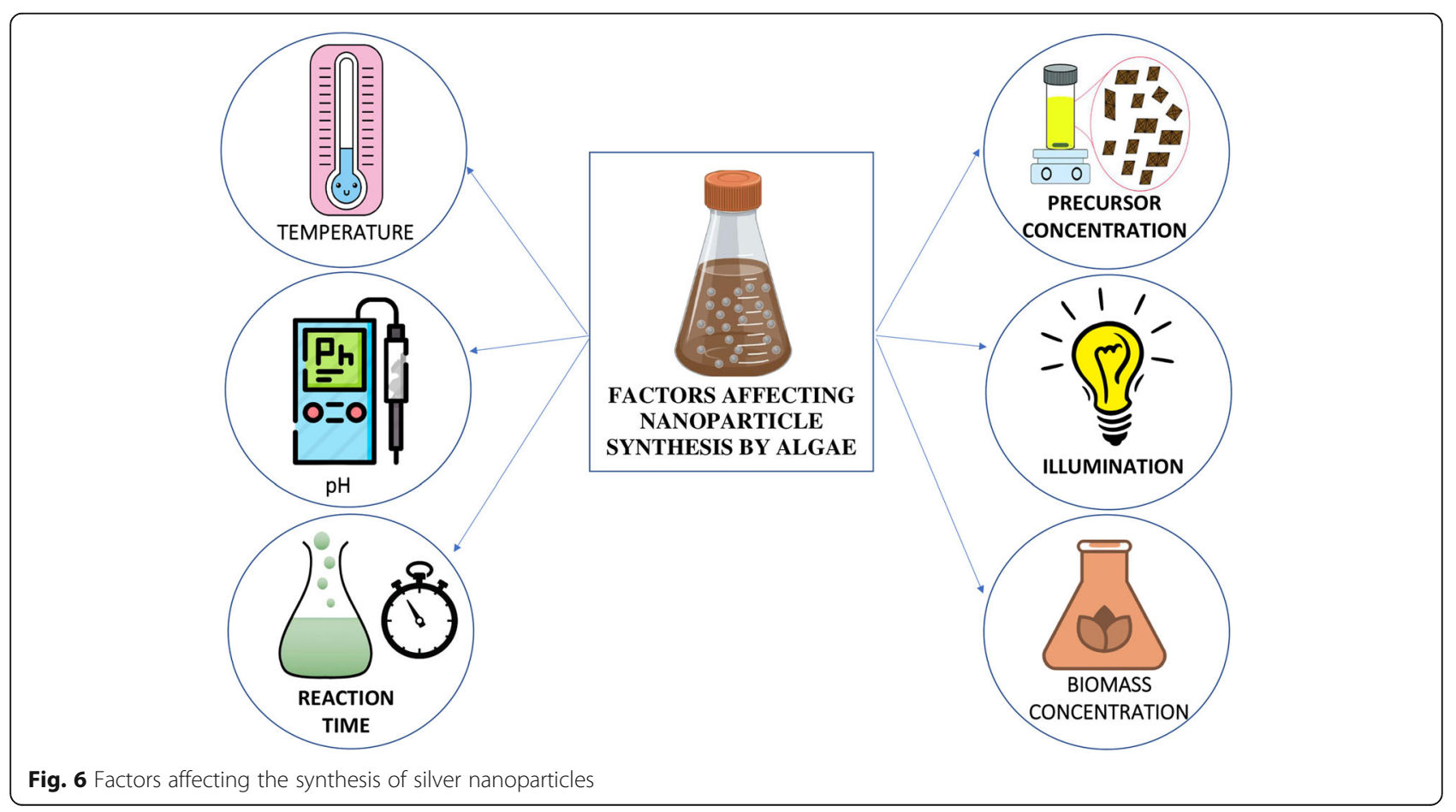


substrate [15]. Aboelfetoh et al. demonstrated the effect of $C$. serrulata extract concentration on the AgNP biosynthesis [108]. They observed that on increasing the concentration of the extract gradually (5 to $20 \%$ ) in $10^{-3}$ $\mathrm{M} \mathrm{AgNO}_{3}$, the intensity of SPR increased and there was a shift towards a lower wavelength $(435 \mathrm{~nm})$. This shift was due to a decrease in the mean size of AgNPs [108]. On further increasing the concentration to $25 \%$ there was a reduction in SPR intensity due to the aggregation of nanoparticles [108]. The study depicts that even though increasing the concentration can increase in production of AgNP, beyond a threshold concentration agglomeration happens. Agglomeration of nanoparticles can cause a reduction in their functional properties and economic importance. Hence for methods involving cellular extract, it is very important to standardize an optimum concentration along with other parameters.

\section{$\mathrm{pH}$}

The size and morphology of the biologically synthesized nanoparticles can be influenced greatly by the change in $\mathrm{pH}[92,109]$. It is because the electrical charge of biomass and capping agents are altered strongly at different $\mathrm{pH}$ conditions which causes alteration in their ability to bind and reduce metal ions. Hamouda et al. showed that the optimum $\mathrm{pH}$ for AgNP synthesis by O. limnetica was 6.7, but as soon as the $\mathrm{pH}$ was altered to 4.7 or 5.7, NP synthesis was completely inhibited [109]. Another group of researchers stated that a large number of functional groups are available for silver binding at a slightly acidic $\mathrm{pH}$ and this allows a large number of $\mathrm{Ag}$ ions to bind and form nanoparticles [110]. Studies related to change in shape and size of nanoparticles by altering the $\mathrm{pH}$ of the reaction medium have also been reported [111]. Several reports exhibit that an acidic medium promotes the production of large-size AgNPs whereas small-size AgNPs were formed in the alkaline medium [112].

\section{Temperature}

Temperature is another important factor that influences the biosynthesis of silver nanoparticles. In general, the rate of reaction and production of NP increases with an increase in temperature [111]. Not only the rate of the reaction increases with the increase in temperature, but it can also help in higher production of NP and regulate the size of the particles too. With an increase in temperature, the size of nanoparticles also increases [113].

Alteration in temperature can also affect the shape of nanoparticles. Lengke et al. reported that during the synthesis of AgNP with cyanobacterium Plectonema boryanum, the shape of the AgNp changed with a temperature change. Spherical silver nanoparticles were observed at all temperatures ranging from 25 to $100{ }^{\circ} \mathrm{C}$ but a octahedral-shaped NP was produced only at 100 ${ }^{\circ} \mathrm{C}$ [77]. Prasad et al. in an experiment found that the average size of nanoparticles synthesized by the brown alga Cystophora moniliformis at a temperature less than $65{ }^{\circ} \mathrm{C}$ was $75 \mathrm{~nm}$. He also reported that the aggregation of nanoparticles occurs at a higher temperature (85-90 ${ }^{\circ} \mathrm{C}$ ) and a cluster of particles with size $>2 \mu \mathrm{m}$ was observed at $95{ }^{\circ} \mathrm{C}$ [114]. Hence, there is a need for optimization of the temperature for AgNP production and the temperature condition is highly dependent on the algal stain and the method being used for the synthesis. This is interesting in another way because by controlling this parameter NP of different sizes can be produced easily.

\section{Incubation time/reaction time}

Biological synthesis of NP involves incubation of the $\mathrm{AgNO}_{3}$ solution with the microorganisms or their extract for a fixed duration used certain physical and chemical conditions. The biosynthesis of silver nanoparticles by algae also depends on the reaction time or incubation time. In general, with an increase in reaction time, the number of nanoparticles increases but only for a certain amount of time. After that, there might be an agglomeration of silver nanoparticles due to their instability. However, if the nanoparticles synthesized are stable then there will be no effect of increasing time on them [115]. The effect of incubation time also depends on the organism that is being used for the synthesis. Kannan et al. observed that Codium capitatum took around $48 \mathrm{~h}$ for the production of nanoparticles from the precursor whereas it took just $30 \mathrm{~min}$ for synthesis by Chaetomorpha linum $[84,116]$. Exposure time can also influence the size of particles.

\section{Precursor concentration}

It is well known that precursor concentration not only influences the yield but also affects the morphology of synthesized nanoparticles. In a study conducted by Rahman et al., the researchers used two different precursor concentrations $(0.650 \mathrm{mM}$ and $1.250 \mathrm{mM})$ for the synthesis of silver nanoparticles using $C$. reinhardtii. They reported that the formation of AgNPs was faster at $0.650 \mathrm{mM}$ of $\mathrm{AgNO}_{3}$ than at $1.250 \mathrm{mM}$. This depicts that the rate of conversion of $\mathrm{Ag}^{+}$to AgNps depends on the concentration of precursors [117]. It has also been observed that precursor concentration directly affects the number of nanoparticles synthesized, i.e. the higher the concentration, the greater the yield. However, the viability of cells gets reduced with higher yield due to the cytotoxic effect of both NPs and cations and therefore changes the yield and morphology of synthesized NP [15]. The size of nanoparticles can also be affected 
by the precursor concentration. With an increase in precursor concentration, the size of NPs also increases [118].

\section{Illumination}

Light can act as a catalyst for many reactions. Illumination is a critical physical factor that can affect the synthesis of AgNP. There are multiple experimental evidence that establish the effect of illumination during nanoparticle synthesis. Patel et al. in an experiment showed that extracellular polysaccharides isolated from the Scenedesmus sp. were able to synthesize silver nanoparticles in the presence of light but failed to do so in the dark. This indicates that how important light is for the synthesis of silver nanoparticles in this condition [101].. Another group of researchers led by Bao et al. reported the same observation by using an aqueous cell extract of Neochloris oleoabundans. They found that the biosynthesis of AgNPs needs illumination of white, blue, or purple light. The same extract failed to show NP synthesis when the reaction was carried out in dark conditions or in the presence of orange or red light [119]. The study clearly indicates that it is not only illumination; there are particular wavelengths that assist in the AgNP synthesis by different methods. Even UV light can affect the size of AgNPs [101].

In a study by El-Naggar et al. on phycocyanin mediated synthesis of AgNP it was reported that the even in presence of light, synthesis of AgNP was impossible if the pigment phycocyanin was omitted from the reaction mixture. They concluded that the chromophores on being exposed to light get excited, and at that condition, they cause a reduction of the $\mathrm{AgNO}_{3}$ in the medium to form AgNP [34].

In a current study by Rahaman et al., it was established that the synthesis of AgNP by extracellular polymeric substances (EPS) of Chlamydomonas reinhardtii is affected by both the EPS concentration and light intensity [120]. The absorption of $\mathrm{Ag}^{+}$was carried out by the EPS molecules but the conversion of $\mathrm{Ag}^{+}$to AgNP was driven by light. With the progress in the reaction condition, the concentration of $\mathrm{H}^{+}$increased thereby causing a decrease in the $\mathrm{pH}$. It was observed that with an increase in the intensity of the light the decrease in $\mathrm{pH}$ and concentration of $\mathrm{Ag}^{+}$also decreased. This observation indicated the involvement of the light in regulating the AgNP production with EPS [120]. Hence, under certain reaction conditions, illumination can assist in the formation of AgNP by causing a reduction of cations of the metal $\mathrm{M}^{\mathrm{n}+}$ to $\mathrm{M}^{0}$; however, the wavelength and the intensity are highly dependent on the components of the system.

\section{Capping agent}

During the bottom-up approach of nanoparticle synthesis, nucleation and growth of nanoparticles occur. The first step of the synthesis, known as the reduction reaction, involves the reduction of metal ion precursors with the help of a reducing agent. This induces the nucleation of the atoms and then the growth of the nuclei (seeds) into metal nanoparticles. There are different theories for the nucleation and growth mechanisms of nanoparticles such as the LaMer mechanism, Ostwald ripening, FinkeWatzky mechanism, coalescence, and oriented attachment, and intra-particle growth. The silver nanoparticle synthesis mostly involves two mechanisms: Ostwald ripening and Coalescence [121]. Ostwald ripening is a thermodynamically driven process in which small nanoparticles are dissolved and are re-deposited onto larger nanoparticles [122]. Due to the high solubility and surface energy of small particles, they dissolve and larger particles grow even more. Coalescence is the attachment of the smaller particles through a random orientation of their lattices to produce larger particles and thereby reducing the number of particles within the solution [121].

Capping agents are amphiphilic molecules that possess a polar head and a non-polar tail region. The polar head group coordinates to the metal atom of the nanocrystals that are formed by agglomeration, whereas the tail region interacts with the surrounding medium [123]. (Fig. 7) Capping agents generally used are ionic and nonionic surfactants and polymers. In bottom-up approaches, the different forces such as Van der Waals interaction, capillary interaction, surface tension, and hydrophobic interaction, and $\mathrm{H}$-bonding effect mediates the self-assembly of nanoparticles. By exploiting these mechanisms using different capping agents, stable metal nanoparticles can be synthesized [124]. The stability, shape, and size of the nanoparticles determine their applications in different fields. Agglomerated silver nanoparticles may not be desired for certain applications like biomedicine, nanosensors, etc. Different capping agents can be utilized to obtain the desired shape and size of AgNPs. Some capping agents have dual roles in reducing and capping the nanoparticles.

\section{Capping agent in green synthesis of silver nanoparticles}

In a study performed by Jayaprakash et al., Silver nanospheres (AgNS) capped with Triton X-100 were synthesized by the microwave-assisted method [125]. There was a dual reduction and capping role for Triton X-100 in the presence of microwave radiations. HR-TEM (High-resolution transmission electron microscopy) revealed the spherical morphology of the AgNS with an average diameter of $5 \mathrm{~nm}$. As stated in previous literature, the Raman spectrum showed different bands due 


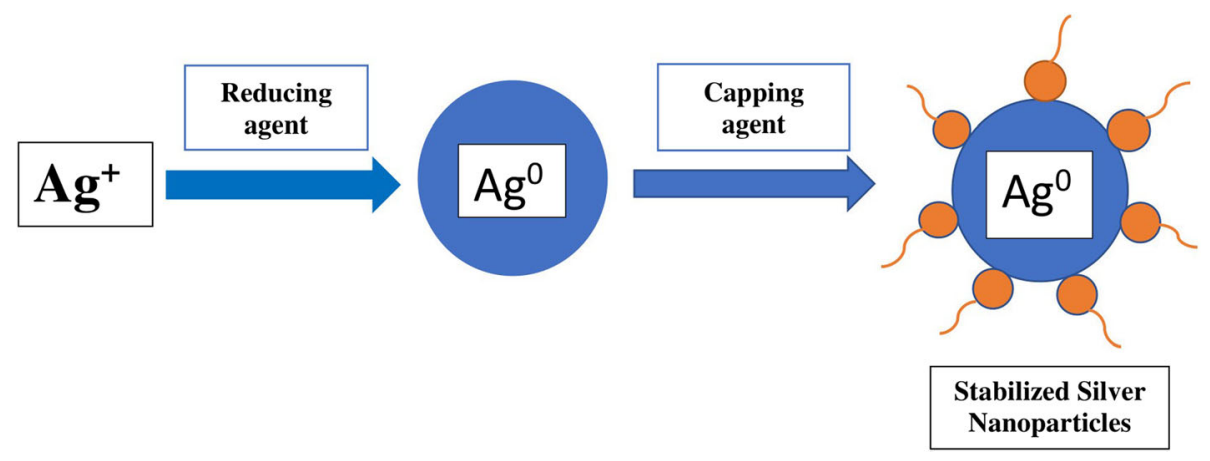

Fig. 7 The action of capping agent on the Ag NP

to Triton X-100 and another additional band at 1608 $\mathrm{cm}^{-1}$ was seen due to the $\mathrm{C}=\mathrm{O}$ stretching vibration in the aldehyde group, which clearly shows that the $-\mathrm{OH}$ group in TX-100 has oxidized through the reduction of $\mathrm{Ag}+$ ions to the $\mathrm{C}=\mathrm{O}$ group. In addition, compared to the Raman bands produced by pure Triton X-100, all the bands observed were shifted to lower wavelengths [125]. In another experiment, Tollens' reagent was used for NP synthesis along with microwave irradiation. The process reported the use of a biopolymer xylan as a capping agent; however, as observed by the researchers, xylan functioned as a reducing agent too.

The diameter of the Ag NPs synthesized by this process was in the range of $20-35 \mathrm{~nm}$ [126].

Plant-mediated synthesis of AgNPs using aqueous extracts of fresh leaves of Impatiens balsamina and Lantana camara as reducing agents was performed and the average size of the AgNPs obtained was less than $24 \mathrm{~nm}$ which was determined using TEM. TEM images revealed the presence of an organic layer around the AgNPs. This layer was due to the presence of polyphenolic compounds like flavonoids and terpenoids which facilitated the reduction of $\mathrm{Ag}^{+}$as well as the capping of the AgNPs [127]. Aloe vera extract was also reported as a reducing and capping agent for the biosynthesis of Ag NPs under microwave irradiation. Ammoniacal silver nitrate solution was used as the metal ion precursor, shape and size of the synthesized NPs were studied by TEM and SEM (Scanning Electron Microscope) imaging. The NPs produced by this method were octahedral in shape and $5-50 \mathrm{~nm}$ in size. The FTIR (Fourier Transform Infrared Spectroscopy) spectrum for the NPs showed a few peaks which indicated the presence of flavanones and terpenoids on the surface of AgNPs as capping agents [128]. Many such studies have proved that the biomolecules present in the plant extracts play the roles of reducing agent and capping agent. Extracellular biosynthesis of AgNPs was carried out using the aqueous culture filtrate of the endophytic fungus Pestalotiopsis microspore. The TEM images showed spherical AgNPs of diameter 2-10 $\mathrm{nm}$ and the FTIR spectrum indicated the presence of phenolic compounds (flavonoids and triterpenoids) and proteins in the fungal culture filtrate which stabilized the AgNPs by acting as capping agents [129]. In another study, the culture filtrate of a filamentous fungus called Fusarium oxysporum was used for the extracellular biosynthesis of AgNPs. The size of the AgNPs was in the range $21.3-37.3 \mathrm{~nm}$ and the spherical shape. The FTIR spectrum of these NPs showed the presence of amide I and amide II in the fungal extract which was the capping agent [130].

The biosynthesis of AgNPs by a new strain of Pseudomonas was performed and spherical polydispersed AgNPs of average size $50 \mathrm{~nm}$ were obtained. However, in this case, the presence of capping proteins on the surface of AgNPs produced by the bacteria was confirmed by the FTIR study. The interactions that stabilized the NP were mostly between the free amine groups and cysteine residues of the protein and the NP [131]. Bacillus subtilis was used in another study for the biosynthesis of AgNPs and spherical-shaped AgNPs of 3 to 20 $\mathrm{nm}$ were obtained. The FTIR spectrum showed some peaks which indicated the existence of proteins that acted as capping agents [132].

Different alga-mediated synthesis of AgNP is well established now. A study involving the use of Chlamydomonas reinhardtii exhibited the involvement of cellar proteins as capping agents. Intracellular synthesis of AgNP was carried out which led to the formation of rounded/rectangular AgNPs of size 5-15 nm and 5-35 $\mathrm{nm}$ respectively. The TEM and SEM images showed bright spots inside the algal cells due to the synthesis of AgNPs and it was observed that the AgNPs were localized in the periplasm and cytoplasm and the basal bodies of the flagella. MALDI-MS MS (Matrix-assisted laser desorption ionization-tandem mass spectrometry) confirmed the function of cellular proteins in biosynthesis and capping. Most of the AgNP-associated proteins were involved in the oxidoreductive mechanism in the algal cells, ATPase activity, sedoheptulose-1,7-bisphosphatase, 
carbonic anhydrase, FNR, SOD, oxygen-evolving enhancer protein, ribulose bisphosphate carboxylase, and nuclear histone (H4). The majority of these proteins acted as reducing as well as capping agents [17]. In another study, the biosynthesis of AgNPs by the freshwater green algae Pithophora oedogonia was carried out and the results of the SEM and DLS (dynamic light scattering) showed the formation of cubic and hexagonal AgNPs of 25-44-nm size. The FTIR spectrum showed certain peaks corresponding to the presence of terpenoids, longchain fatty acids, and secondary amide derivatives which capped the AgNPs and stabilized them [133].

Biogenic synthesis of AgNPs was also carried by cellfree extract of Saccharomyces boulardii. TEM images showed the presence of monodispersed spherical AgNPs with the size range of $3-10 \mathrm{~nm}$. The FTIR results

Table $\mathbf{5}$ List of different capping agents in chemical and biological syntheses

\begin{tabular}{|c|c|c|c|c|c|}
\hline Method & $\begin{array}{l}\text { Silver } \\
\text { precursor }\end{array}$ & Reducing agent & Stabilizing/capping agents & Size $(\mathrm{nm})$ \& shape & Reference \\
\hline $\begin{array}{l}\text { Chemical } \\
\text { reduction }\end{array}$ & $\mathrm{AgNO}_{3}$ & Trisodium citrate & $\mathrm{NaBH}_{4}$ & $\begin{array}{l}60 \& 100 \mathrm{~nm}\left(0.75 \mathrm{ml} \text { and } 1 \mathrm{ml} \text { of } \mathrm{NaBH}_{4}\right. \\
\text { respectively) } \\
\text { Spherical }\end{array}$ & [136] \\
\hline $\begin{array}{l}\text { Chemical } \\
\text { reduction }\end{array}$ & $\mathrm{AgNO}_{3}$ & Sodium citrate & $\mathrm{NaBH}_{4}$ & $\begin{array}{l}\sim 23 \\
\text { Spherical }\end{array}$ & [137] \\
\hline $\begin{array}{l}\text { Chemical } \\
\text { reduction }\end{array}$ & $\mathrm{AgNO}_{3}$ & $\begin{array}{l}\text { MSA } \\
\text { (mercaptosuccinic } \\
\text { acid) }\end{array}$ & MSA & $\begin{array}{l}\sim 65 \\
\text { Spherical }\end{array}$ & {$[137]$} \\
\hline $\begin{array}{l}\text { Chemical } \\
\text { reduction }\end{array}$ & $\mathrm{AgNO}_{3}$ & $\mathrm{NaBH}_{4}$ & Thioctic acid & $\begin{array}{l}\sim 44 \\
\text { Spherical }\end{array}$ & [137] \\
\hline $\begin{array}{l}\text { Chemical } \\
\text { reduction }\end{array}$ & $\mathrm{AgNO}_{3}$ & - & PVP & $\begin{array}{l}15 \\
\text { Spherical }\end{array}$ & [138] \\
\hline $\begin{array}{l}\text { Chemical } \\
\text { reduction }\end{array}$ & $\mathrm{AgNO}_{3}$ & - & Citrate & $\begin{array}{l}12.6 \\
\text { Spherical }\end{array}$ & [138] \\
\hline $\begin{array}{l}\text { Chemical } \\
\text { reduction }\end{array}$ & $\mathrm{AgNO}_{3}$ & - & BPEI (branched polyethyleneimine) & $\begin{array}{l}11.5 \\
\text { Spherical }\end{array}$ & [138] \\
\hline $\begin{array}{l}\text { Chemical } \\
\text { reduction }\end{array}$ & $\mathrm{AgNO}_{3}$ & Trisodium citrate & SDS (sodium dodecyl sulphate) & $\begin{array}{l}19 \\
\text { Spherical }\end{array}$ & [139] \\
\hline $\begin{array}{l}\text { Chemical } \\
\text { reduction }\end{array}$ & $\mathrm{AgNO}_{3}$ & Trisodium citrate & PEG & $\begin{array}{l}50 \\
\text { Spherical }\end{array}$ & [139] \\
\hline By plant & $\mathrm{AgNO}_{3}$ & Cleome viscosa & $\begin{array}{l}\text { Alkaloids, phenolic compounds, } \\
\text { tannins, proteins }\end{array}$ & $\begin{array}{l}5-30 \\
\text { Spherical }\end{array}$ & {$[140]$} \\
\hline Plant & $\mathrm{AgNO}_{3}$ & Callicarpa maingayi & $\begin{array}{l}\text { Alkaloids, flavonoids, }-\mathrm{OH},-\mathrm{NH},-\mathrm{C}=\mathrm{O} \\
\text { groups }\end{array}$ & $\begin{array}{l}13-15.6 \\
\text { Spherical }\end{array}$ & [141] \\
\hline Plant & $\mathrm{AgNO}_{3}$ & Citrus limon & Citric acid & $\begin{array}{l}16-18 \\
\text { Spherical }\end{array}$ & [142] \\
\hline Plant & $\mathrm{AgNO}_{3}$ & Murraya koenigii & $\begin{array}{l}\text { Carboxylic acids, alcohol, ether, } \\
\text { proteins }\end{array}$ & $\begin{array}{l}5-20 \\
\text { Spherical }\end{array}$ & [143] \\
\hline Fungi & $\mathrm{AgNO}_{3}$ & Fusarium oxysporum & Proteins & $\begin{array}{l}10-20 \\
\text { Spherical }\end{array}$ & {$[66]$} \\
\hline Fungi & $\mathrm{AgNO}_{3}$ & Aspergillus oryzae & Proteins & $\begin{array}{l}<105 \\
\text { (depending on } \mathrm{pH} \text {, temp, and conc. of } \\
\mathrm{AgNO}_{3} \text { ) } \\
\text { Spherical }\end{array}$ & [67] \\
\hline Fungi & $\mathrm{AgNO}_{3}$ & Trichoderma reesei & Proteins & $\begin{array}{l}5-50 \\
\text { Spherical }\end{array}$ & {$[68]$} \\
\hline Bacteria & $\mathrm{AgNO}_{3}$ & E.Coli & $\begin{array}{l}-\mathrm{NH},-\mathrm{OH} \text {, Carbonyl, } \mathrm{CN} \text { triple bond } \\
\text { in proteins }\end{array}$ & $\begin{array}{l}118 \\
\text { Spherical }\end{array}$ & [144] \\
\hline Bacteria & $\mathrm{AgNO}_{3}$ & Bacillus cereus & Proteins & $\begin{array}{l}10-30 \\
\text { Spherical }\end{array}$ & {$[69]$} \\
\hline Brown algae & $\mathrm{AgNO}_{3}$ & Padina sp. & $\begin{array}{l}\text { Polyphenols, Fatty acids } \\
\text { (Hexadecanoic acid) }\end{array}$ & $\begin{array}{l}25-61.4 \\
\text { Spherical }\end{array}$ & [145] \\
\hline $\begin{array}{l}\text { Marine red } \\
\text { algae }\end{array}$ & $\mathrm{AgNO}_{3}$ & Spyridia fusiforms & Proteins, Secondary cyclic alcohols & $\begin{array}{l}5-50 \\
\text { Mostly spherical, some triangular and } \\
\text { rounded rectangular }\end{array}$ & {$[146]$} \\
\hline
\end{tabular}


showed certain bands that corresponded to the involvement of proteins in the reduction and stabilization/capping of the AgNPs. Further, the UV-Visible spectra of the cell-free extract showed strong absorption at $280 \mathrm{~nm}$ which may be due to the aromatic amino acid residues (tyrosine and tryptophan) present in the proteins. To confirm the role of proteins in the biosynthesis of stabilization of AgNPs, the yeast cells were subjected to heat treatment at various stages of growth. The heatkilled yeast cells were unable to synthesize AgNPs, this was probably due to the denaturation of the proteins by heat treatment [134].. Baker's yeast (Saccharomyces cerevisiae) was used for the extracellular synthesis of AgNPs. Oval-shaped AgNPs of average size $16.07 \mathrm{~nm}$ were obtained which was determined using XRD (X-ray diffraction). The FTIR revealed notable peaks which showed the capping of AgNPs by active biomolecules, alcohols, phenols, carboxylic acids and aromatic amines. These capping agents lead to effective stabilization of the AgNPs [135]. Table 5 shows other different capping agents in chemical and biological synthesis.

\section{Advantages of using external capping agent}

As we have seen that nanoparticles are of great use and have different applications in the field of medicines, pharmaceuticals, cosmetics, electronics, etc. but they can still be hazardous to the environment depending on the approach of synthesis [147]. With time, AgNPs tend to form aggregates and these aggregates are sometimes toxic to the environment. So, the stabilization of silver nanoparticles is an important issue. Stabilization can also be carried out by using external capping agents or surface modifiers [148]. The selection of capping agents should be done carefully as it will determine several different physical and chemical properties of the nanoparticles. While selecting a capping agent, one should keep in mind that the substance should be non-toxic, biodegradable, well dispersed, bio soluble, and biocompatible [147]. Sodium Dodecyl Sulphate (SDS), a commonly used capping agent is capable of reducing the toxicity of nanoparticle s[149]. Hamouda et al. compared the antimicrobial activity of silver nanoparticles with and without capping agent (SDS) and found that silver nanoparticles along with SDS have high antimicrobial activity than nanoparticles synthesized without capping agent [150]. The use of an external capping agent along with the biological method of synthesis can help in producing AgNP with desired properties.

\section{Conclusion}

There is a wide application of Ag-NPs in the field of medicines, cosmetics, biosensors, therapeutics, etc. In the last few years, several attempts have been made to develop new methods of green synthesis. Green synthesis mostly involves the use of microbes or plants and hence its environment-friendly and sustainable approach towards nanoparticle synthesis. This review article highlights the wide application of AgNPs and their different modes of synthesis. Among all the living microorganisms, the synthesis of AgNPs by algae is the most popular because of their cost-effective method of production and extraction. Alga-mediated synthesis can be carried out using cell extract, cell-free extract, and living cells. Most of these methods involve the participation of biomolecules as capping agents for the synthesis. Despite having several advantages, the production of silver nanoparticles using algae is still limited due to the lack of information about the exact mechanism of synthesis. Further analysis is required to resolve the problems related to kinetics, yield, and cell viability to construct large-scale bioreactors for commercial-level production. In addition, extensive research is also required to recognize and evaluate the role of different biomolecules as reducing and capping agents.

However, if the process can be coupled with the use of external capping agents, then the stability of the NPs can be under manual regulation. This will probably allow obtaining NPs of higher efficiency. A regulated and qualitative synthesis of algae-mediated NPs can be accomplished with new emerging technologies, which will help to improve the characteristics and functionality of these nanoparticles for their industrial application.

\section{Abbreviations \\ aP: Algal proteins; CA: Carbonic anhydrase; CTAB: Cetyltrimethylammonium bromide; FNR: Ferredoxin NADP ${ }^{+}$reductase; FTIR: Fourier transform infrared spectroscopy; HR-TEM: High-Resolution transmission electron microscopy; MALDI-MS MS: Matrix-assisted laser desorption ionization-tandem mass spec- trometry; MRSA: Methicillin-resistant Staphylococcus aureus; DMF: N, N- dimethylformamide; NAI: N-Acetylimidazole; NP: Nanoparticles; OEE: Oxygen- evolving enhancer protein; PEG: Polyethylene glycol; PVA: Polyvinyl alcohol; SDS-PAGE: Sodium dodecyl sulphate-polyacrylamide gel electrophoresis; SBPase: Sedoheptulose-1, 7-bisphosphatase; AgNPs: Silver nanoparticles; $\mathrm{AgNO}_{3}$ : Silver Nitrate; AgNS: Silver nanospheres; SOD: Superoxide dismutase; SPR: Surface plasmon resonance; TEM: Transmission electron microscope; XRD: X-ray diffraction}

\section{Acknowledgements}

Not applicable.

\section{Authors' contributions}

All authors certify that they have participated sufficiently in contributing to the intellectual content, concept, and writing the manuscript and all authors have read and approved the manuscript. D.C. and V.S.V collected the material and wrote the review, B.D. (corresponding author) framed the structure of the article and formatted it. B.D confirms that all listed authors have approved the manuscript before submission, including the names and order of authors.

\section{Funding}

Not applicable.

Availability of data and materials Not applicable. 


\section{Declarations}

Ethics approval and consent to participate

Not applicable.

\section{Consent for publication}

Not applicable.

\section{Competing interests}

The authors declare that they have no competing interests.

Received: 22 June 2021 Accepted: 10 August 2021

Published online: 24 August 2021

\section{References}

1. Komolafe O (2004) Antibiotic resistance in bacteria - an emerging public health problem. Malawi Med J. 15(2). https://doi.org/10.4314/mmj.v15i2.1 0780

2. Kim SH, Lee HS, Ryu DS, Choi SJ, Lee DS (2011) Antibacterial activity of silver-nanoparticles against Staphylococcus aureus and Escherichia coli. Korean J Microbiol Biotechnol 39(1):77-85

3. Prabhu S, Poulose EK (2012) Silver nanoparticles: mechanism of antimicrobial action, synthesis, medical applications, and toxicity effects. Int Nano Lett 2(1):32. https://doi.org/10.1186/2228-5326-2-32

4. Gholami-Shabani M, Akbarzadeh A, Norouzian D, Amini A, Gholami-Shabani Z, Imani A, Chiani M, Riazi G, Shams-Ghahfarokhi M, Razzaghi-Abyaneh M (2014) Antimicrobial activity and physical characterization of silver nanoparticles green synthesized using nitrate reductase from Fusarium oxysporum. Appl Biochem Biotechnol. United States 172(8):4084-4098. https://doi.org/10.1007/s12010-014-0809-2

5. Ahmed S, Ahmad M, Swami BL, Ikram S (2016) A review on plants extract mediated synthesis of silver nanoparticles for antimicrobial applications: A green expertise. J Adv Res 7(1):17-28. https://doi.org/10.1016/j.jare.2015.02 007

6. Castro-Longoria E, Vilchis-Nestor AR, Avalos-Borja M (2011 Elsevier B.V) Biosynthesis of silver, gold and bimetallic nanoparticles using the filamentous fungus Neurospora crassa. Colloids Surfaces B Biointerfaces 83(1):42-48. https://doi.org/10.1016/j.colsurfb.2010.10.035

7. Parveen K, Banse V, Ledwani L (2016) Green synthesis of nanoparticles: Their advantages and disadvantages. AIP Conf Proc 1724. https://doi.org/10.1 $063 / 1.4945168$

8. Guilger-Casagrande M, de Lima R (2019) Synthesis of Silver Nanoparticles Mediated by Fungi: A Review. Front Bioeng Biotechnol 7(October):1-16. https://doi.org/10.3389/fbioe.2019.00287

9. Dawadi S, Katuwal S, Gupta A, Lamichhane U, Thapa R, Jaisi S, Parajuli N (2021) Current Research on Silver Nanoparticles: Synthesis, Characterization, and Applications. J Nanomaterials:23. https://doi.org/10.1155/2021/6687290

10. Xu L, Wang YY, Huang J, Chen CY, Wang ZX, Xie H (2020) Silver nanoparticles: Synthesis, medical applications and biosafety. Theranostics 10(20):8996-9031. https://doi.org/10.7150/thno.45413

11. Salomoni R, Léo P, Montemor AF, Rinaldi BG, Rodrigues M (2017) Antibacterial effect of silver nanoparticles in Pseudomonas aeruginosa. Nanotechnol Sci Appl 10:115-121. https://doi.org/10.2147/NSA.S133415

12. Logeswari P, Silambarasan S, Abraham J (2015) 'Synthesis of silver nanoparticles using plants extract and analysis of their antimicrobial property', Journal of Saudi Chemical Society. King Saud Univ 19(3):311-317. https://doi.org/10.1016/j.jscs.2012.04.007

13. Ansari MA (2018 eCAM) One-Pot Facile Green Synthesis of Silver Nanoparticles Using Seed Extract of Phoenix dactylifera and Their Bactericidal Potential against MRSA. Evid Based Complement Altern Med 2018:1860280-1860289. https://doi.org/10.1155/2018/1860280

14. Syafiuddin A, Salmiati SMR, Beng Hong Kueh A, Hadibarata T, Nur H (2017) A Review of Silver Nanoparticles: Research Trends, Global Consumption, Synthesis, Properties, and Future Challenges. J Chin Chem Soc 64(7):732756. https://doi.org/10.1002/jccs.201700067

15. Rahman A, Kumar S, Nawaz T (2020) Biosynthesis of Nanomaterials Using Algae. Microalgae Cultivation Biofuels Prod Elsevier Inc. https://doi.org/10.1 016/b978-0-12-817536-1.00017-5

16. Majeed, H. M. and Wadee, S. A. 'Antibacterial activity and mechanism of nickel nanoparticles against multidrug resistant pseudomonas aeruginosa',
Ann Trop Med Public Health, 22(Special Issue 6), 2019 pp. 1469-1487. doi: https://doi.org/10.36295/ASRO.2019.220618.

17. Haider A, Kang I (2014) Preparation of Silver Nanoparticles and Their Industrial and Biomedical Applications: A Comprehensive Review. Adv Mater Sci Eng 2015:1-16. https://www.hindawi.com/journals/amse/2015/165257/

18. Mathur $P$, Jha S, Ramteke S, Jain NK (2018) Pharmaceutical aspects of silver nanoparticles. Artif Cells Nanomed Biotechnol 46(sup 1):115-126. https://doi. org/10.1080/21691401.2017.1414825

19. Yan X, He B, Liu L, Qu G, Shi J, Hu L, Jiang G (2018) 'Antibacterial mechanism of silver nanoparticles in Pseudomonas aeruginosa: proteomics approach', Metallomics. R Soc Chem 10(4):557-564. https://doi.org/10.1039/ C7MT00328E

20. Burdușel A-C, Gherasim O, Grumezescu AM, Mogoantă L, Ficai A, Andronescu E (2018) Biomedical Applications of Silver Nanoparticles: An Up-to-Date Overview. Nanomaterials (Basel, Switzerland). MDPI 8(9):681. https://doi.org/10.3390/nano8090681

21. Rajeshkumar S, Kannan C, Annadurai G (2012) Synthesis and characterization of antimicrobial silver nanoparticles using marine brown seaweed Padina tetrastromatica. Drug Invent Today 4(10):511-513

22. Thangaraju N, Venkatalakshmi RP, Chinnasamy A, Kannaiyan P (2012) Synthesis of silver nanoparticles and the antibacterial and anticancer activities of the crude extract of Sargassum polycystum C. Agardh. Nano Biomed Eng 4(2):89-94. https://doi.org/10.5101/nbe.v3i1.p89-94

23. Kumar P, Senthamil Selvi S, Govindaraju M (2013) Seaweed-mediated biosynthesis of silver nanoparticles using Gracilaria corticata for its antifungal activity against Candida spp. Appl Nanosci (Switzerland) 3(6):495500. https://doi.org/10.1007/s13204-012-0151-3

24. Yousefzadi M, Rahimi Z, Ghafori V (2014) The green synthesis, characterization and antimicrobial activities of silver nanoparticles synthesized from green alga Enteromorpha flexuosa (wulfen) J. Agardh. Mater Let Elsevier 137:1-4. https://doi.org/10.1016/j.matlet.2014.08.110

25. Govindaraju K, Kiruthiga V, Kumar VG, Singaravelu G (2009) Extracellular synthesis of silver nanoparticles by a marine alga, Sargassum wightii Grevilli and their antibacterial effects. J Nanosci Nanotechnol. United States 9(9): 5497-5501. https://doi.org/10.1166/jnn.2009.1199

26. Vijayan SR, Santhiyagu $P$, Singamuthu M, Kumari Ahila N, Jayaraman $R$, Ethiraj K (2014) Synthesis and characterization of silver and gold nanoparticles using aqueous extract of seaweed, turbinaria conoides, and their antimicrofouling activity. Sci World J (February). https://doi.org/10.11 55/2014/938272

27. Lashgarian H, Karkhane M, Alhameedawi A, Marzban A (2021) PhycoMediated Synthesis of Ag/AgCl Nanoparticles Using Ethanol Extract of a Marine Green Algae, Ulva Fasciata Delile with Biological Activity. Biointerface Res Appl Chem:11. https://doi.org/10.33263/BRIAC116.1454514554

28. Sondi I, Salopek-Sondi B (2004) Silver nanoparticles as antimicrobial agent: A case study on E. coli as a model for Gram-negative bacteria. J Colloid Interface Sci 275(1):177-182. https://doi.org/10.1016/j.jcis.2004. 02.012

29. Raffi M, Akhter Jl, Hamed A, Hassan M (2008) Antibacterial characterization of silver nanoparticles against E. Coli ATCC-15224. J Mater Sci Technol 24(2):192-196

30. Gomathi AC, Xavier Rajarathinam SR, Mohammed Sadiq A, Rajeshkumar S (2019) Anticancer activity of silver nanoparticles synthesized using aqueous fruit shell extract of Tamarindus indica on MCF-7 human breast cancer cell line. J Drug Deliv Sci Technol. Elsevier 55:101376. https://doi.org/10.1016/j. jddst.2019.101376

31. Thapa RK, Kim JH, Jeong J-H, Shin BS, Choi H-G, Yong CS, Kim JO (2017) Silver nanoparticle-embedded graphene oxide-methotrexate for targeted cancer treatment. Colloids Surf B Biointerfaces. Netherlands 153:95-103. https://doi.org/10.1016/j.colsurfb.2017.02.012

32. Rajeshkumar S, Malarkodi C, Vanaja M, Annadurai G (2016) Anticancer and enhanced antimicrobial activity of biosynthesizd silver nanoparticles against clinical pathogens. J Mol Struct. Elsevier Ltd 1116:165-173. https://doi.org/1 0.1016/j.molstruc.2016.03.044

33. Gopu M, Kumar P, Selvankumar T et al (2021) Green biomimetic silver nanoparticles utilizing the red algae Amphiroa rigida and its potent antibacterial, cytotoxicity and larvicidal efficiency. Bioprocess Biosyst Eng: 217-223. https://doi.org/10.1007/s00449-020-02426-1

34. El-Naggar NE-A, Hussein MH, El-Sawah AA (2017) Bio-fabrication of silver nanoparticles by phycocyanin, characterization, in vitro anticancer activity against breast cancer cell line and in vivo cytotxicity. Sci Rep 7(1):10844. https://doi.org/10.1038/s41598-017-11121-3 
35. Venkatesan J, Kim SK, Shim MS (2016) Antimicrobial, antioxidant, and anticancer activities of biosynthesized silver nanoparticles using marine algae ecklonia cava. Nanomaterials 6(12). https://doi.org/10.3390/nano6120235

36. Patra JK, Das G, Fraceto LF, Campos EVR, Rodriguez-Torres MDP, AcostaTorres LS, Diaz-Torres LA, Grillo R, Swamy MK, Sharma S, Habtemariam S, Shin HS (2018) Nano based drug delivery systems: recent developments and future prospects. J Nanobiotechno 16(71) https://doi.org/10.1186/s12 951-018-0392-8

37. Ivanova N, Gugleva V, Dobreva M, Pehlivanov I, Stefanov S, Andonova V (2019) Silver Nanoparticles as Multi-Functional Drug Delivery Systems. Nanomedicines. https://doi.org/10.5772/intechopen.80238

38. Konop M, Damps T, Misicka A, Rudnicka L (2016) Certain Aspects of Silver and Silver Nanoparticles in Wound Care: A Minireview. J Nanomaterials. E 2016:7614753-7614710. https://doi.org/10.1155/2016/7614753

39. Gunasekaran T, Nigusse T, Dhanaraju MD (2012) Silver nanoparticles as real topical bullets for wound healing. J Am Coll Clin Wound Spec. Elsevier 3(4): 82-96. https://doi.org/10.1016/j.jcws.2012.05.001

40. Thirumurugan G, Veni VS, Ramachandran S, Seshagiri Rao JVLN, Dhanaraju MD (2011) Superior wound healing effect of topically delivered silver nanoparticle formulation using eco-friendly potato plant pathogenic fungus: synthesis and characterization. J Biomed Nanotechnol 7(5):659-666. https:// doi.org/10.1166/jbn.2011.1336

41. Bindhu MR, Umadevi M (2014) Silver and gold nanoparticles for sensor and antibacterial applications. Spectrochim Acta Part A Mol Biomol Spectrosc: 37-45. https://doi.org/10.1016/.s.saa.2014.02.119

42. Vasileva P, Alexandrova T, Karadjova I (2017) Application of Starch-Stabilized Silver Nanoparticles as a Colorimetric Sensor for Mercury(II) in $0.005 \mathrm{~mol} / \mathrm{L}$ Nitric Acid. J Chem. Edited by R. Comparelli. Hindawi 2017:68979606897969. https://doi.org/10.1155/2017/6897960

43. Tashkhourian J, Sheydaei O (2017) Chitosan Capped Silver Nanoparticles as Colorimetric Sensor for the Determination of Iron(III). Ana Bioanal Chem Res 4(2):249-260. https://doi.org/10.22036/abcr.2017.69942.1127

44. Roy B, Bairi P, Nandi AK (2011) Selective colorimetric sensing of mercury(ii) using turn off-turn on mechanism from riboflavin stabilized silver nanoparticles in aqueous medium. Analyst 136(18):3605-3607. https://doi. org/10.1039/c1an15459a

45. Chen L, Fu X, Lu W, Chen L (2013) Highly Sensitive and Selective Colorimetric Sensing of $\mathrm{Hg} 2+$ Based on the Morphology Transition of Silver Nanoprisms. ACS Appl Mater Interfaces. American Chemical Society 5(2): 284-290. https://doi.org/10.1021/am3020857

46. Prasad KS, Shruthi G, Shivamallu C (2018) Functionalized Silver Nano-Sensor for Colorimetric Detection of $\mathrm{Hg}(2+)$ Ions: Facile Synthesis and Docking Studies. Sensors (Basel, Switzerland). MDPI 18(8):2698. https://doi.org/10.33 90/s18082698

47. Prosposito P, Burratti L, Bellingeri A, Protano G, Faleri C, Corsi I, Battocchio C, Iucci G, Tortora L, Secchi V, Franchi S, Venditti I (2019) Bifunctionalized Silver Nanoparticles as Hg(2+) Plasmonic Sensor in Water: Synthesis, Characterizations, and Ecosafety. Nanomaterials (Basel, Switzerland). MDPI 9(10):1353. https://doi.org/10.3390/nano9101353

48. Li H, Cui Z, Han C (2009) Glutathione-stabilized silver nanoparticles as colorimetric sensor for Ni2+ ion. Sensors Actuators B Chem 143(1):87-92. https://doi.org/10.1016/j.snb.2009.09.013

49. Ghodake GS, Shinde SK, Saratale RG, Kadam AA, Saratale GD, Syed A, Ameen F, Kim DY (2018) Colorimetric detection of Cu2+ based on the formation of peptide-copper complexes on silver nanoparticle surfaces. Beilstein J Nanotechnol 9(1):1414-1422. https://doi.org/10.3762/bjnano.9.134

50. Vasileva P, Dobrev S, Karadjova I (2019) Colorimetric detection of iron(III) based on sensitive and selective plasmonic response of starch-coated silver nanoparticles. In: Proc.SPIE. https://doi.org/10.1117/12.2553972

51. Annadhasan M, Muthukumarasamyvel T, Sankar Babu VR, Rajendiran N (2014) Green synthesized silver and gold nanoparticles for colorimetric detection of $\mathrm{Hg}_{2}+, \mathrm{Pb} 2+$, and $\mathrm{Mn} 2+$ in aqueous medium. ACS Sustainable Chem Eng 2(4):887-896. https://doi.org/10.1021/sc400500z

52. Shrivas K, Sahu S, Patra GK, Jaiswal NK, Shankar R (2016) 'Localized surface plasmon resonance of silver nanoparticles for sensitive colorimetric detection of chromium in surface water, industrial waste water and vegetable samples', Analytical Methods. R Soc Chem 8(9):2088-2096. https://doi.org/10.1039/c5ay03120f

53. Thanachayanont C, Photiphitak C, Rakkwamsuk P, Muthitamongkol P, SaeKung C (2011) Effect of silver nanoparticle size on efficiency enhancement of dye-sensitized solar cells. Int J Photoenergy 2011:1-8. https://doi.org/1 $0.1155 / 2011 / 258635$

54. Ihara M, Kanno M, Inoue S (2010) Photoabsorption-enhanced dye-sensitized solar cell by using localized surface plasmon of silver nanoparticles modified with polymer. Phys E Low Dimensional Syst Nanostructures. Elsevier 42(10): 2867-2871. https://doi.org/10.1016/j.physe.2010.04.001

55. Yusuf M (2019) Silver Nanoparticles: Synthesis and Applications. In: Martínez L, Kharissova O, Kharisov B (eds) Handbook of Ecomaterials. Springer, Cham https://doi.org/10.1007/978-3-319-68255-6_16

56. Tran Q, Nguyen VQ, Le A (2018) Corrigendum: Silver nanoparticles: synthesis, properties, toxicology, applications and perspectives. Adv Nat Sci Nanosci Nanotechnol 9:049501

57. Pyatenko A, Shimokawa K, Yamaguchi M, Nishimura O, Suzuki M (2004) Synthesis of silver nanoparticles by laser ablation in pure water. Appl Phys A Mater Sci Process 79(4-6):803-806. https://doi.org/10.1007/s00339-004-2841-5

58. Iravani S, Korbekandi H, Mirmohammadi SV, Zolfaghari B (2014) Synthesis of silver nanoparticles: chemical, physical and biological methods. Res Pharm Sci 9(6):385-406

59. Jawaad RS, Sultan KF, Al-Hamadani AH (2014) Synthesis of silver nanoparticles. J Eng Appl Sci 9(4):586-592. https://doi.org/10.5772/ intechopen.75363

60. Malik MA, Wani MY, Hashim MA (2012) Microemulsion method: A novel route to synthesize organic and inorganic nanomaterials. 1st Nano Update. Arabian J Chem. King Saud University 5(4):397-417. https://doi.org/10.1016/ j.arabjc.2010.09.027

61. Dang TMD, Le TT, Fribourg-Blanc E, Dang MC (2012) Influence of surfactant on the preparation of silver nanoparticles by polyol method. Adv Nat Sci Nanosci Nanotechnol 3(3). https://doi.org/10.1088/2043-6262/3/3/035004

62. Dondi R, Su W, Griffith GA, Clark G, Burley GA (2012) Highly size- and shapecontrolled synthesis of silver nanoparticles via a templated tollens reaction. Small 8(5):770-776. https://doi.org/10.1002/smll.201101474

63. Roy A, Bulut O, Some S, Mandal AK, Yilmaz MD (2019) Green synthesis of silver nanoparticles: Biomolecule-nanoparticle organizations targeting antimicrobial activity. RSC Adv. Royal Society of Chemistry 9(5):2673-2702. https://doi.org/10.1039/c8ra08982e

64. Zhao X, Xia Y, Li Q, Ma X, Quan F, Geng C, Han Z (2014) Microwave-assisted synthesis of silver nanoparticles using sodium alginate and their antibacterial activity. Colloids Surfaces A Physicochem Eng Aspects. Elsevier B.V 444:180-188. https://doi.org/10.1016/j.colsurfa.2013.12.008

65. Nadaroglu H, Alayli A, Nadaroğlu H, Alayli Güngör A, Ince S (2017) Synthesis of Nanoparticles by Green Synthesis Method. Int J Innovative Res Rev 1(1):6-9

66. Husseiny SM, Salah TA, Anter HA (2015) Biosynthesis of size controlled silver nanoparticles by Fusarium oxysporum, their antibacterial and antitumor activities. Beni-Suef Univ J Basic Appl Sci. The Authors 4(3):225-231. https:// doi.org/10.1016/j.bjbas.2015.07.004

67. Phanjom P, Ahmed G (2017) Effect of different physicochemical conditions on the synthesis of silver nanoparticles using fungal cell filtrate of Aspergillus oryzae (MTCC No. 1846) and their antibacterial effect. Adv Nat Sci Nanosci Nanotechnol. IOP Publishing 8(4). https://doi.org/10.1088/20436254/aa92bc

68. Vahabi K, Mansoori GA, Karimi S (2011) Biosynthesis of Silver Nanoparticles by Fungus Trichoderma Reesei (A Route for Large-Scale Production of AgNPs). Insci J 1(1):65-79. https://doi.org/10.5640/insc.010165

69. Prakash A, Sharma S, Ahmad N, Ghosh A, Sinha P (2011) Synthesis of Agnps By Bacillus Cereus Bacteria and Their Antimicrobial Potential. J Biomater Nanobiotechnol 02(02):155-161. https://doi.org/10.4236/jbnb.2011.22020

70. Keat $\mathrm{CL}$, Aziz A, Eid AM, Elmarzugi NA (2015) Biosynthesis of nanoparticles and silver nanoparticles. Bioresources Bioprocess. Springer Berlin Heidelberg. https://doi.org/10.1186/s40643-015-0076-2

71. Natsuki J, Natsuki T, Hashimoto Y (2015) A Review of Silver Nanoparticles: Synthesis Methods, Properties and Applications. 4(5):325-332. https://doi. org/10.11648/j.jmsa.20150405.17

72. Gudikandula K, Maringanti SC (2016) Synthesis of silver nanoparticles by chemical and biological methods and their antimicrobial properties. https:// doi.org/10.1080/17458080.2016.1139196

73. LewisOscar F, Vismaya S, Arunkumar M, Thajuddin N, Dhanasekaran D, Nithya C (2016) Algal Nanoparticles: Synthesis and Biotechnological Potentials. Algae Organ Imminent Biotechnol. https://doi.org/10.5772/62909

74. Negi S, Singh V (2018) Algae: A potential source for nanoparticle synthesis. J Appl Nat Sci 10(4):1134-1140. https://doi.org/10.31018/jans.v10i4.1878 
75. Sudha SS, Rajamanickam K, Rengaramanujam J (2013) Microalgae mediated synthesis of silver nanoparticles and their antibacterial activity against pathogenic bacteria. Indian J Exp Biol 51(5):393-399

76. Ali DM, Sasikala M, Gunasekaran M, Thajuddin N (2011) Biosynthesis And Characterization Of Silver Nanoparticles Using Marine Cyanobacterium , Oscillatoria Willei Ntdm01 Type Sec . amides, freeNH (trans ) Charged amines ( $\mathrm{C}=\mathrm{NH}+$ ) Organo-silicon compounds Aliphatic esters Secondary alcohols Vibration Mode. Digest J Nanomaterials Biostructures Vol. 6(2):385390

77. Lengke MF, Fleet ME, Southam G (2007) Biosynthesis of silver nanoparticles by filamentous cyanobacteria from a silver(I) nitrate complex. Langmuir 23(5):2694-2699. https://doi.org/10.1021/la0613124

78. Mahdieh M, Zolanvari A, Azimee AS, Mahdieh M (2012) Green biosynthesis of silver nanoparticles by Spirulina platensis. Sci Iranica. Elsevier B.V. 19(3): 926-929. https://doi.org/10.1016/j.scient.2012.01.010

79. Govindaraju K, Basha SK, Kumar VG, Singaravelu G (2008) Silver, gold and bimetallic nanoparticles production using single-cell protein (Spirulina platensis) Geitler. J Mater Sci 43(15):5115-5122. https://doi.org/10.1007/s1 0853-008-2745-4

80. Soleimani, M. and Habibi-Pirkoohi, M. 'Biosynthesis of Silver Nanoparticles using Chlorella vulgaris and Evaluation of the Antibacterial Efficacy Against Staphylococcus aureus', Avicenna J Med Biotechnol. Avicenna Research Institute, 2017 9(3), pp. 120-125.

81. Ebrahiminezhad A, Bagheri M, Taghizadeh SM, Berenjian A, Ghasemi Y (2016) Biomimetic synthesis of silver nanoparticles using microalgal secretory carbohydrates as a novel anticancer and antimicrobial. Adv Nat Sci Nanosci Nanotechnol 7(1). https://doi.org/10.1088/2043-6262/7/1/015018

82. El-Kassas HY, Ghobrial MG (2017) Biosynthesis of metal nanoparticles using three marine plant species: anti-algal efficiencies against "Oscillatoria simplicissima". Environ Sci Pollut Res. Environmental Science and Pollution Research 24(8):7837-7849. https://doi.org/10.1007/s11356-017-8362-5

83. Kathiraven T, Sundaramanickam A, Shanmugam N, Balasubramanian T (2015) Green synthesis of silver nanoparticles using marine algae Caulerpa racemosa and their antibacterial activity against some human pathogens. Appl Nanosci 5(4):499-504. https://doi.org/10.1007/s13204-014-0341-2

84. Kannan RRR, Stirk WA, Van Staden J (2013) Synthesis of silver nanoparticles using the seaweed Codium capitatum P.C. Silva (Chlorophyceae). South Afr J Botany. South African Association of Botanists 86:1-4. https://doi.org/10.1 016/j.sajb.2013.01.003

85. Rajesh S, Patric Raja D, Rathi JM, Sahayaraj K (2012) Biosynthesis of silver nanoparticles using Ulva fasciata (Delile) ethyl acetate extract and its activity against Xanthomonas campestris pv. malvacearum. J Biopesticides 5(SUPPL):119-128

86. Shiny PJ, Mukherjee A, Chandrasekaran N (2013) Marine algae mediated synthesis of the silver nanoparticles and its antibacterial efficiency. Int J Pharm Pharm Sci 5(2):239-241

87. Sahayaraj K, Rajesh S, Rathi JM (2012) Silver nanoparticles biosynthesis using marine alga Padina pavonica (Linn.) and its microbicidal activity. Dig J Nanomaterials Biostructures 7(4):1557-1567

88. Shukla MK, Singh RP, Reddy CRK, Jha B (2012) Synthesis and characterization of agar-based silver nanoparticles and nanocomposite film with antibacterial applications. Bioresour Technol 107:295-300. https://doi.org/1 0.1016/j.biortech.2011.11.092

89. Roni M, Murugan K, Panneerselvam C, Subramaniam J, Nicoletti M, Madhiyazhagan P, Dinesh D, Suresh U, Khater HF, Wei H, Canale A, Alarfaj AA, Munusamy MA, Higuchi A, Benelli G (2015) Characterization and biotoxicity of Hypnea musciformis-synthesized silver nanoparticles as potential eco-friendly control tool against Aedes aegypti and Plutella xylostella. Ecotoxicol Environ Saf. Elsevier 121:31-38. https://doi.org/10.1016/ j.ecoenv.2015.07.005

90. Sharma A, Sharma S, Sharma K, Chetri SPK, Vashishtha A, Singh P, Kumar R, Rathi B, Agrawal V (2016) Algae as crucial organisms in advancing nanotechnology: a systematic review. J Appl Phycol 28(3):1759-1774. https://doi.org/10.1007/s10811-015-0715-1

91. Singh I, Singh S (2019) Study of algal mediated biosynthesis of nanoparticle: future of green nanotechnology. Curr Life Sci 5(1):7-14. https://doi.org/10.52 81/zenodo.2666643

92. Rajkumar R, Ezhumalai G, Gnanadesigan M (2021) A green approach for the synthesis of silver nanoparticles by Chlorella vulgaris and its application in photocatalytic dye degradation activity. Environ Technol Innov 21:101282. https://doi.org/10.1016/j.eti.2020.101282
93. Khan AU, Khan M, Malik N, Cho MH, Khan MM (2019) Recent progress of algae and blue-green algae-assisted synthesis of gold nanoparticles for various applications. Bioprocess Biosyst Eng 42(1):1-15. https://doi.org/10.1 007/s00449-018-2012-2

94. Omar HH, Bahabri FS, El-Gendy AM (2017) Biopotential application of synthesis nanoparticles as antimicrobial agents by using Laurencia papillosa. Int J Pharmacol 13(3):303-312. https://doi.org/10.3923/ijp.2017.303.312

95. Baltazar-Encarnación E, Escárcega-González CE, Vasto-Anzaldo XG, CantúCárdenas ME, Morones-Ramírez JR (2019) Silver Nanoparticles Synthesized through Green Methods Using Escherichia coli Top 10 (Ec-Ts) Growth Culture Medium Exhibit Antimicrobial Properties against Nongrowing Bacterial Strains. J Nanomaterials:4637325. https://doi.org/10.1155/2019/463 7325

96. Dahoumane SA, Mechouet M, Wijesekera K, Filipe CDM, Sicard C, Bazylinski DA, Jeffryes C (2017) Algae-mediated biosynthesis of inorganic nanomaterials as a promising route in nanobiotechnology-a review. Green Chem 19(3):552-587. https://doi.org/10.1039/c6gc02346k

97. Kaduková J, Velgosová O, Mražíková A, Marcinčáková R (2014) The effect of culture age and initial silver concentration on biosynthesis of $\mathrm{Ag}$ nanoparticles. Nova Biotechnol Chim 13(1):28-37. https://doi.org/10.2478/ nbec-2014-0004

98. El-Naggar NEA, Hussein MH, Shaaban-Dessuuki SA, Dalal SR (2020) Production, extraction and characterization of Chlorella vulgaris soluble polysaccharides and their applications in AgNPs biosynthesis and biostimulation of plant growth. Sci Rep 10(1):1-19. https://doi.org/10.1038/ s41598-020-59945-w

99. Jena J, Pradhan N, Dash BP, Panda PK, Mishra BK (2015) Pigment mediated biogenic synthesis of silver nanoparticles using diatom Amphora sp. and its antimicrobial activity. J Saudi Chem Soc 19(6):661-666. https://doi.org/10.1 016/j.jscs.2014.06.005

100. Chetia L, Kalita D, Ahmed GA (2017) Synthesis of Ag nanoparticles using diatom cells for ammonia sensing. Sensing Bio Sensing Res 16:55-61. https://doi.org/10.1016/j.sbsr.2017.11.004

101. Patel V, Berthold D, Puranik P, Gantar M (2015, Elsevier B.V) Screening of cyanobacteria and microalgae for their ability to synthesize silver nanoparticles with antibacterial activity. Biotechnol Rep 5(1):112-119. https://doi.org/10.1016/j.btre.2014.12.001

102. Zahran MK, Mohammed HA (2021) Green synthesis of silver nanoparticles using polysaccharide extracted from Laurencia obtuse algae. Egypt J Appl Sci 36(1):9-16. https://doi.org/10.21608/ejas.2021.152332

103. Aarthy A, Kumari S, Turkar P, Subramanian S (2018) An insight on algal cell disruption for biodiesel production. Asian J Pharm Clin Res 11(2):21-26. https://doi.org/10.22159/ajpcr.2018.v11i2.22481

104. Xie J, Lee JY, Wang DIC, Ting YP (2007) Silver Nanoplates: From Biological to Biomimetic Synthesis - ACS Nano (ACS Publications). ACS Nano 1(5):429439. https://doi.org/10.1021/nn7000883

105. Barwal I, Ranjan P, Kateriya S, Yadav SC (2011) Cellular oxido-reductive proteins of Chlamydomonas reinhardtii control the biosynthesis of silver nanoparticles. J Nanobiotechnol 9(1):1-12. https://doi.org/10.1186/1477-31 55-9-56

106. Sharma G, Jasuja ND, Kumar M, Ali MI (2015) Biological synthesis of silver nanoparticles by cell-free extract of spirulina platensis. J Nanotechnol 2015: 1-6. https://doi.org/10.1155/2015/132675

107. Dahoumane SA, Mechouet M, Alvarez FJ, Agathos SN, Jeffryes C (2016) Microalgae: An outstanding tool in nanotechnology. Rev Bionatura 1(4):196201. https://doi.org/10.21931/RB/2016.01.04.7

108. Aboelfetoh EF, El-Shenody RA, Ghobara MM (2017) Eco-friendly synthesis of silver nanoparticles using green algae (Caulerpa serrulata): reaction optimization, catalytic and antibacterial activities. Environ Monit Assess 189, 189(7, 7). https://doi.org/10.1007/s10661-017-6033-0

109. Hamouda RA, Hussein MH, Abo-elmagd RA, Bawazir SS (2019) Synthesis and biological characterization of silver nanoparticles derived from the cyanobacterium Oscillatoria limnetica. Sci Rep 9(1):1-17. https://doi.org/10.1 038/s41598-019-49444-y

110. Gan PP, Ng SH, Huang Y, Li SFY (2012) Green synthesis of gold nanoparticles using palm oil mill effluent (POME): a low-cost and ecofriendly viable approach. Bioresour Technol 113:132-135. https://doi.org/10.1 016/j.biortech.2012.01.015

111. Hasan M, Ullah I, Zulfiqar H, Naeem K, lqbal A, Gul H, Ashfaq M, Mahmood $N$ (2018) Biological entities as chemical reactors for synthesis of 
nanomaterials: Progress, challenges and future perspective. Mater Today Chem 8:13-28. https://doi.org/10.1016/j.mtchem.2018.02.003

112. Siddiqui MN, Redhwi HH, Achilias DS, Kosmidou E, Vakalopoulou E, loannidou MD (2018, Springer US) Green Synthesis of Silver Nanoparticles and Study of Their Antimicrobial Properties. J Polym Environ 26(2):423-433. https://doi.org/10.1007/s10924-017-0962-0

113. Sathishkumar M, Sneha K, Yun YS (2010, Elsevier Ltd) Immobilization of silver nanoparticles synthesized using Curcuma longa tuber powder and extract on cotton cloth for bactericidal activity. Bioresource Technology 101(20):7958-7965. https://doi.org/10.1016/j.biortech.2010.05.051

114. Prasad TNVKV, Kambala VSR, Naidu R (2013) Phyconanotechnology: Synthesis of silver nanoparticles using brown marine algae Cystophora moniliformis and their characterisation. J Appl Phycol 25(1):177-182. https:// doi.org/10.1007/s10811-012-9851-z

115. Mohandass C, Vijayaraj AS, Rajasabapathy R, Satheeshbabu S, Rao SV, Shiva C, De-Mello L (2013) Biosynthesis of silver nanoparticles from marine seaweed Sargassum cinereum and their antibacterial activity. Indian J Pharm Sci 75(5):606-610

116. Dhavale R, Jadhav S, Sibi G (2020) Microalgae mediated silver nanoparticles (Ag-NPs) synthesis and their biological activities. J Crit Rev 7(2):15-20. https://doi.org/10.31838/jcr.07.02.04

117. Rahman A, Kumar S, Bafana A, Dahoumane SA, Jeffryes C (2019) Biosynthetic conversion of Ag+ to highly Stable Ag0 nanoparticles by wild type and cell wall deficient strains of chlamydomonas reinhardtii. Molecules 24(1). https://doi.org/10.3390/molecules24010098

118. Panchangam RL, Upputuri RTP (2019) In vitro biological activities of silver nanoparticles synthesized from scedosporium sp. Isolated from soil. Braz J Pharm Sci 55:1-8. https://doi.org/10.1590/s2175-97902019000200254

119. Bao Z, Lan CQ (2018, Elsevier B.V) Mechanism of light-dependent biosynthesis of silver nanoparticles mediated by cell extract of Neochloris oleoabundans. Colloids Surfaces B Biointerfaces 170:251-257. https://doi. org/10.1016/j.colsurfb.2018.06.001

120. Rahman A, Kumar S, Bafana A, Lin J, Dahoumane SA, Jeffryes C (2019) A Mechanistic View of the Light-Induced Synthesis of Silver Nanoparticles Using Extracellular Polymeric Substances of Chlamydomonas reinhardtii. Molecules (Basel, Switzerland) 24(19):3506. https://doi.org/10.3390/ molecules 24193506

121. Thanh NTK, Maclean N, Mahiddine S (2014) Mechanisms of nucleation and growth of nanoparticles in solution. Chem Rev 114(15):7610-7630. https:// doi.org/10.1021/cr400544s

122. Zhang Z, Wang Z, He S, Wang C, Jin M, Yin Y (2015) Redox reaction induced Ostwald ripening for size- and shape-focusing of palladium nanocrystals. Chem Sci. Royal Society of Chemistry 6(9):5197-5203. https:// doi.org/10.1039/c5sc01787d

123. Gulati S, Sachdeva M, Bhasin KK (2018) Capping agents in nanoparticle synthesis: Surfactant and solvent system. AIP Conf Proc 1953. https://doi. org/10.1063/1.5032549

124. Shi X, Han S, Sanedrin RJ, Galvez C, Ho DG, Hernandez B, Zhou F, Selke M (2002) Formation of Cobalt Oxide Nanotubes: Effect of Intermolecular Hydrogen Bonding between Co(III) Complex Precursors Incorporated onto Colloidal Templates. Nano Lett 2(4):289-293. https://doi.org/10.1021/nl01 56944

125. Jayaprakash N, Kennedy LJ, Vijaya JJ (2013) Microwave-Assisted Synthesis and Characterization of Triton X 100 Capped Silver Nanospheres. J Dispersion Sci Technol 34(11):1597-1602. https://doi.org/10.1080/01932691.2 012.745377

126. Luo Y, Shen S, Luo J, Wang X, Sun R (2015) Green synthesis of silver nanoparticles in xylan solution via Tollens reaction and their detection for Hg2+. Nanoscale 7(2):690-700. https://doi.org/10.1039/c4nr05999a

127. Aritonang HF, Koleangan H, Wuntu AD (2019) Synthesis of silver nanoparticles using aqueous extract of medicinal plants' (impatiens balsamina and lantana camara) fresh leaves and analysis of antimicrobial activity. Int J Microbiol 2019:1-8. https://doi.org/10.1155/2019/8642303

128. Logaranjan K, Raiza AJ, Gopinath SCB, Chen Y, Pandian K (2016) Shape- and Size-Controlled Synthesis of Silver Nanoparticles Using Aloe vera Plant Extract and Their Antimicrobial Activity. Nanoscale Res Lett 11(1). https://doi. org/10.1186/s11671-016-1725-x

129. Netala VR, Bethu MS, Pushpalatha B, Baki VB, Aishwarya S, Rao JV (2016) Biogenesis of silver nanoparticles using endophytic fungus Pestalotiopsis microspora and evaluation of their antioxidant and anticancer activities. Int J Nanomed 11:5683-5696. https://doi.org/10.2147/IJN.S112857
130. Ahmed AA, Hamzah H, Maaroof M (2018) Analyzing formation of silver nanoparticles from the filamentous fungus fusarium oxysporum and their antimicrobial activity. Turk J Biol 42(1):54-62. https://doi.org/10.3906/biy-171 $0-2$

131. John MS, Nagoth JA, Ramasamy KP, Mancini A, Giuli G, Natalello A, Ballarini P, Miceli C, Pucciarelli S (2020) Synthesis of bioactive silver nanoparticles by a pseudomonas strain associated with the antarctic psychrophilic protozoon euplotes focardii. Mar Drugs 18(1). https://doi.org/10.3390/md18010038

132. Alsamhary KI (2020) Eco-friendly synthesis of silver nanoparticles by Bacillus subtilis and their antibacterial activity. Saudi J Biol Sci 27(8):2185-2191. https://doi.org/10.1016/j.sjbs.2020.04.026

133. Sinha SN, Paul D, Halder N, Sengupta D, Patra SK (2015) Green synthesis of silver nanoparticles using fresh water green alga Pithophora oedogonia (Mont.) Wittrock and evaluation of their antibacterial activity. Appl Nanosci 5(6):703-709. https://doi.org/10.1007/s13204-014-0366-6

134. Kaler A, Jain S, Banerjee UC (2013) Green and rapid synthesis of anticancerous silver nanoparticles by Saccharomyces boulardii and insight into mechanism of nanoparticle synthesis. BioMed Res Int 2013:1-8. https:// doi.org/10.1155/2013/872940

135. Olobayotan I, Akin-Osanaiye B (2019) Biosynthesis of silver nanoparticles using baker's yeast, Saccharomyces cerevisiae and its antibacterial activities. Access Microbiol:24-25. https://doi.org/10.1099/acmi.ac2019.po0316

136. Phan CM, Nguyen HM (2017) Role of Capping Agent in Wet Synthesis of Nanoparticles. J Phys Chem A 121(17):3213-3219. https://doi.org/10.1021/a cs.jpca.7b02186

137. Matea CT, Mocan T, Tabaran F, Pop T, Mosteanu O, Mocan L, Zdrehus C (2018) Evaluation of capping agents for silver nanoparticles. Stud Univ Babes Bolyai Chem 63(4):95-102. https://doi.org/10.24193/subbchem.2018.4.07

138. Chen S, Drehmel JR, Penn RL (2020) Facile Synthesis of Monodispersed Ag NPs in Ethylene Glycol Using Mixed Capping Agents. ACS Omega 5(11): 6069-6073. https://doi.org/10.1021/acsomega.9b04492

139. Pinzaru I, Coricovac D, Dehelean C, Moacă EA, Mioc M, Baderca F, Sizemore I, Brittle S, Marti D, Calina CD, Tsatsakis AM, Şoica C (2018) Stable PEGcoated silver nanoparticles - A comprehensive toxicological profile. Food Chem Toxicol 111(February 2018):546-556. https://doi.org/10.1016/j.fct.201 7.11.051

140. Lakshmanan G, Sathiyaseelan A, Kalaichelvan PT, Murugesan K (2018) Plantmediated synthesis of silver nanoparticles using fruit extract of Cleome viscosa L.: Assessment of their antibacterial and anticancer activity. Karbala Int J Mod Sci. Elsevier Ltd 4(1):61-68. https://doi.org/10.1016/j.kijoms.2017.1 0.007

141. Shameli K, Ahmad MB, Jaffar Al-Mulla EA, Ibrahim NA, Shabanzadeh $P$, Rustaiyan A, Abdollahi Y, Bagheri S, Abdolmohammadi S, Usman MS, Zidan M (2012) Green biosynthesis of silver nanoparticles using callicarpa maingayi stem bark extraction. Molecules 17(7):8506-8517. https://doi.org/1 0.3390/molecules17078506

142. Mohapatra B, Kaintura R, Singh J, Kuriakose S, Mohapatra S (2015) Biosynthesis of high concentration, stable aqueous dispersions of silver nanoparticles using Citrus limon extract. Adv Mater Lett 6(3):228-234. https://doi.org/10.5185/amlett.2015.5731

143. Qais FA, Shafiq A, Khan HM, Husain FM, Khan RA, Alenazi B, Alsalme A, Ahmad I (2019) Antibacterial effect of silver nanoparticles synthesized using Murraya koenigii (L.) against multidrug-resistant pathogens. Bioinorg Chem Appl. https://doi.org/10.1155/2019/4649506

144. Koilparambil D, Kurian LC, Vijayan S, Manakulam Shaikmoideen J (2016) Green synthesis of silver nanoparticles by Escherichia coli : Analysis of antibacterial activity. J Water Environ Nanotechnol 1(1):63-74. https://doi. org/10.7508/jwent.2016.01.008

145. Bhuyar P, Rahim MHA, Sundararaju S, Ramaraj R, Maniam GP, Govindan N (2020) Synthesis of silver nanoparticles using marine macroalgae Padina sp. and its antibacterial activity towards pathogenic bacteria. Beni-Suef Univ J Basic Appl Sci 9(1). https://doi.org/10.1186/s43088-019-0031-y

146. Murugesan S, Bhuvaneswari S, Sivamurugan V (2017) Green Synthesis, Characterization of Silver Nanoparticles of a Marine Red Alga Spyridia Fusiformis and Their Antibacterial Activity. Int J Pharm Pharm Sci 9(5):192. https://doi.org/10.22159/ijpps.2017v9i5.17105

147. Javed R, Zia M, Naz S, Aisida SO, ul Ain N, Ao Q (2020) Role of capping agents in the application of nanoparticles in biomedicine and environmental remediation: recent trends and future prospects. J Nanobiotechnol. BioMed Central 18(1):1-15. https://doi.org/10.1186/s12951020-00704-4 
148. Hamouda RA, Abd El-Mongy M, Eid KF (2019 Elsevier Ltd) Comparative study between two red algae for biosynthesis silver nanoparticles capping by SDS: Insights of characterization and antibacterial activity. Microbial Pathog 129:224-232. https://doi.org/10.1016/j.micpath.2019.02.016

149. Ju-Nam Y, Lead JR (2008) Manufactured nanoparticles: An overview of their chemistry, interactions and potential environmental implications. Sci Total Environ. Elsevier B.V 400(1-3):396-414. https://doi.org/10.1016/j.scitotenv.2 008.06 .042

150. El Fatah Hamouda RA, El-Mongy MA, Eid KF (2018) Antibacterial activity of silver nanoparticles using ulva fasciata extracts as reducing agent and sodium dodecyl sulfate as stabilizer. Int J Pharmacol 14(3):359-368. https:// doi.org/10.3923/ijp.2018.359.368

\section{Publisher's Note}

Springer Nature remains neutral with regard to jurisdictional claims in published maps and institutional affiliations.

\section{Submit your manuscript to a SpringerOpen ${ }^{\mathcal{O}}$ journal and benefit from:}

- Convenient online submission

- Rigorous peer review

- Open access: articles freely available online

- High visibility within the field

- Retaining the copyright to your article

Submit your next manuscript at $\boldsymbol{\nabla}$ springeropen.com 